\title{
ANALISIS METODE PERHITUNGAN PPH 21 GAJI PEGAWAI TETAP TERHADAP LABA PADA PT. ABC
}

Nur Rachmah Wahidah

Dosen Prodi D-III Sekretari Universitas Pamulang

Nurrachmah32@gmail.com

\begin{abstract}
Abstrak-Tujuan yang ingin dicapai dari penelitian ini adalah untuk mengetahui metode perhitungan pph 21 Gaji pegawai tetap terhadap laba pada PT. ABC. Data penelitian diperoleh penulis melalui penelitian lapangan baik dengan cara observasi maupun wawancara serta didukung dengan peneltian pustaka. Metode Analisis yang digunakan penulis adalah metode analisis deskriptif yang bersifat komparatif yaitu dengan cara mengumpulkan data dan informasi yang berkaitan dengan penerapan PPH21. Dari Hasil Penelitian dapat disimpulkan bahwa metode yang digunakan adalah 3 yaitu metode yang di tanggung karyawan, metode yang ditanggung perusahaan dan metode grossup.
\end{abstract}

\section{Kata Kunci : Perhitungan PPh 21, Laba}

\begin{abstract}
The objective to be achieved from this research is to find out the pph 21 calculation method for salaries of permanent employees to profits at $P T$. A $B C$. The research data obtained by the author through field research both by observation and interview and supported by library research. The analysis method used by the author is a comparative descriptive analysis method that is by collecting data and information relating to the application of PPH21. From the results of the study it can be concluded that the method used is 3, the method at the responsibility of the employee, the method borne by the company and the gross method.
\end{abstract}

Keywords: 21 PPh calculation, Profit

\section{PENDAHULUAN}

\section{Latar Belakang Masalah}

Dalam kondisi perekonomian saat ini, peningkatan penerimaan Negara dari sumber penerimaan yang mandiri sangat dibutuhkan. Kemampuan untuk mengelola keuangan Negara secara mandiri dapat dicapai jika suatu Negara mampu memperoleh sumber penerimaan yang bersumber dari Negara itu sendiri yang salah satunya adalah berasal dari pajak. Pajak sebagai unsur utama penerimaan Negara memiliki target yang ditentukan dalam Anggaran Pendapatan dan Belanja Negara (APBN). Peningkatan target penerimaan pajak secara keseluruhan akan diiringi dengan peningkatan penerimaan masing-masing jenis pajak setiap tahunnya. 
Pajak merupakan salah satu unsur penting dalam operasional perusahan.Terlebih lagi bagi perusahaan yang berkala nasional. Pajak adalah Iuran rakyat kepada kas Negara berdasarkan Undang- undang (yang dapat dipaksakan) dengan tiada mendapatkan jasa timbal yang langsung dapat ditujukan dan yang digunakan untuk membayar pengeluaran umum. Undang-undang perpajakan 2000 pada dasarnya telah menjabarkan pajak sebagai kewajiban bagi setiap warga negara Indonesia sekaligus juga menetapkan masyarakat wajib pajak sebagai subjek dalam pemenuhan kewajiban perpajakan, akan tetapi potensi pajak pemasukan yang legal sulit masuk ke Indonesia. Wajib pajak perseorangan maupun wajib pajak badan diperlukan sebagai subjek dalam Sistem pemungutan pajak, khususnya dalam pajak Penghasilan $(\mathrm{PPh})$.

Peluang melakukan penghematan pada PPh Badan salah satunya dapat dilakaukan pada biaya-biaya yang berkaitan dengan kesejahteraan karyawan di antaranya adalah pada PPh Pasal 21 atas Penghasilan yang di terima oleh karyawan. Dalam menghitung besarnya PPh Pasal 21 terdapat 2 (dua) metode pemotongan pajak yang dapat dipilih oleh perusahan dalam penerapan pemungutan PPh Pasal 21 karyawan. Metode Pertama Net Method, merupakan metode pemotongan pajak dimana PPh Pasal 21 karyawan ditanggung oleh perusahaan. Metode kedua Gross Metode, Merupakan metode pemotongan pajak dimana perusahaan memberikan tunjangan pajak dengan metode Gross Up yang ditentukan dari jumlah Penghasilan Kena Pajak (PKP). Penerapan metode Gross Up ini merupakan aplikasi dari keputusan Dirjen pajak No, keputusan 545/PJ/2000PER 31/PJ/2009.

Laba adalah kelebihan pendapatan atas beban atau kerugian yang terkait dalam operasi atau usaha perusahan untuk memperoleh pendapatan pada suatu periode tertentu. Laba merupakan Fenomena yang umum terjadi sebagai usaha manajemen untuk mengurangi fluktuasi laba yang dilaporkan, tindakan perataan laba adalah suatu sarana yang dapat digunakan manajeman untuk mengurangi fluktuasi pelaporan penghasilan.

Berdasarkan Latar Belakang Masalah mengenai pajak di atas, dalam penelitian ini bermaksud mengadakan penelitian lebih lanjut mengenai masalah tersebut dengan mengambil judul “Analisis Metode Perhitungan PPh Pasal 21 Gaji Pegawai Tetap Terhadap Laba Pada "PT.ABC" 


\section{Identifikasi Masalah}

Berdasarkan uraian latar belakang masalah di atas, terdapat beberapa pokok permasalahan yang dapat dirangkum dalam pernyataan penelitian sebagai berikut:

1. Perhitungan PPh pasal 21 belum sesuai dengan Undang-undang yang telah ditetapkan

2. Tingkat laba pada perusahaan masih fluktuasi karena pengaruh metode perhitungan $\mathrm{PPh}$ pasal 21.

3. Masih adanya pegawai yang tidak menerima tunjangan PPh Pasal 21 setiap bulan.

4. Masih adanya ketertutupan antara perusahan dengan karyawan mengenai PPh Pasal 21.

\section{Pembatasan Masalah}

Sehubungan dengan keterbatasan waktu, tenaga dan biaya, maka secara lebih spesifik penulis membatasi permasalahan yang hanya meliputi perhitungan PPh pasal 21 terhadap laba perusahaan di PT. ABC.

1. Pengertian PPh pasal 21 dan Laba

a. Menurut Waluyo. (2009;191) merupakan Pajak penghasilan yang dikenakan atas penghasilan berupa gaji, upah, honorium, tunjangan dan pembayaran sehubungan denagn pekerjaan, jasa atau kegiatan yang dilakukan oleh wajib pajak orang pribadi.

b. Menurut Menteri Keuangan Nomor 252/PMK 01/2008 tentang ketentuan umum petunjuk Pelaksanaan Pemotongan Pajak Atas Penghasilan Sehubungan Dengan Pekerjaan, Jasa, dan Kegiatan Orang Pribadi. Dalam ketentuan Pasal tersebut yang menjadi Pegawai Tetap Adalah Pegawai yang menerima atau memperoleh penghasilan dalam jumlah tertentu secara teratur, termasuk anggota dewan komisaris dan anggota dewan pengawas yang secara teratur terus menerus ikut mengelola kegiatan perusahan secara langsung, serta pegawai yang bekerja berdasarkan kontrak untuk suatu jangka waktu tertentu sepanjang pegawai yang bersangkutan bekerja penuh (full time) dalam pekerjaan tersebut. Penghasilan Pegawai Tetap yang bersifat Teratur adalah penghasilan bagi pegawai tetap berupa gaji atau upah, segala macam tunjangan, dan imabalan dengan nama apapun yang diberikan secara periodik berdasarkan ketentuan yang ditetapkan oleh pemberi kerja, termasuk uang lembur. Penghasilan Pegawai Tetap pada suatu perusahaan ada yang bersifat tidak teratur dan bersifat teratur. Penghasilan 
pegawai tetap Bersifat Tidak Teratur adalah penghasilan bagi pegawai tetap selain penghasilan yang bersifat teratur, yang diterima sekali dalam satu tahun atau periode lainnya, antara lain berupa bonus, Tunjangan Hari Raya (THR), Jasa Produksi, Tantiem, gratifikasi atau imbalan sejenis lainnya dengan nama apapun.

c. Menurut Toto Sucipto (2006:81) Laba adalah kelebihan pendapatan atas beban atau kerugian yang terkait dalam operasi atau usaha perusahan untuk memperoleh pendapatan pada suatu periode tertentu.

2. Pembatasan tempat penelitian atau objek

Penelitian ini di lakukan di "PT. ABC"

3. Pembatasan Data atau Waktu

Waktu penelitian yang dilakukan dari April 2014 sampai Desember 2014.

\section{Perumusan Masalah}

Dari latar belakang, identifikasi dan pembatasan masalah yang telah dipaparkan maka penulisan perumusan masalah utama yang akan menjadi bahasan pokok dalam penelitian ini mencakup permasalahan mengenai PPh pasal 21 di atas, yaitu:

1. Apakah prosedur pelaksanaan perhitungan PPh Pasal 21 gaji pegawai sesuai dengan prosedur perpajakaan?

2. Apakah yang menjadi penyebab metode perhitungan $\mathrm{PPh}$ pasal 21 pada tingkat laba perusahaan sehingga masih fluktuasi?

3. Apakah semua karyawan PT. ABC mendapatkan tunjangan PPh Pasal 21 setiap bulan?

4. Apakah PT. ABC terbuka mengenai PPh Pasal 21 terhadap karyawan yang sudah dipotong pajak?

\section{Tujuan dan Manfaat Penelitian}

1. Tujuan Penelitian

Tujuan dari penelitian ini adalah untuk menjawab pertanyaan yang menjadi fokus dalam penelitian ini. Oleh karena itu, berdasarkan permasalahan yang telah diuraikan di atas maka tujuan yang dicapai dalam penelitian proposal adalah:

a. Untuk mengetahui prosedur pelaksaan perhitungan $\mathrm{PPh}$ pasal 21 gaji pegawai sesuai denagn prosedur perpajakan. 
b. Untuk mengetahui penyebab metode perhitungan $\mathrm{PPh}$ pasal 21 pada tingkat laba perusahaan sehingga masih fruktuasi.

c. Untuk mengetahui semua karyawan PT. ABC mendapatkan tunjangan PPh Pasal 21 setiap bulan.

d. Untuk mengetahui PT. ABC terbuka mengenai PPh Pasal 21 terhadap karyawan yang sudah dipotong pajak.

\section{Manfaat Penelitian}

Adapun manfaat penelitian ini adalah:

1. Manfaat Praktis

Hasil penelitian ini dapat bermanfaat sebagai bahan pertimbangan dalam mengevaluasi efektifitas dan efisiensi.

2. Manfaat Teoritis

a. Bagi Penulis

Sebagai bahan Informasi ilmiah dalam rangka mengembangkan ilmu pengetahuan khususnya di bidang perpajakan mengenai cara perhitungan pajak.

b. Bagi Universitas

Hasil penelitian ini dapat dijadikan sebagai bahan referensi perpustakan, serta di jadikan sebagai perbandingan penelitian bagi peneliti yang memiliki objek penelitian yang sejenis.

\section{Kerangka Pemikiran}

Menurut Sugiono (2009) Kerangka pemikiran adalah kegiatan penelitian, mulai dari tahap awal sampai tahap akhir harus merupakan urut-urutan logis dari pemikiran peneliti untuk memecahkan suatu masalah penelitian, yang dituangkan dalam bentuk bagan dengan penjelasannya. Adapun pengertian bagan yakni gambaran atau sketsa buram untuk memperlihatkan atau menerangkan sesuatu. Data maupun informasi yang ingin disampaikan direalisasikan melalui gambar. Bagan ada yang berbentuk diagram mempunyai bentuk yang beragam, antara lain: lingkaran, garis, pohon, dan batang. Sedangkan beberapa ahli memberi definisi kerangka berfikir adalah sebagai berikut : 


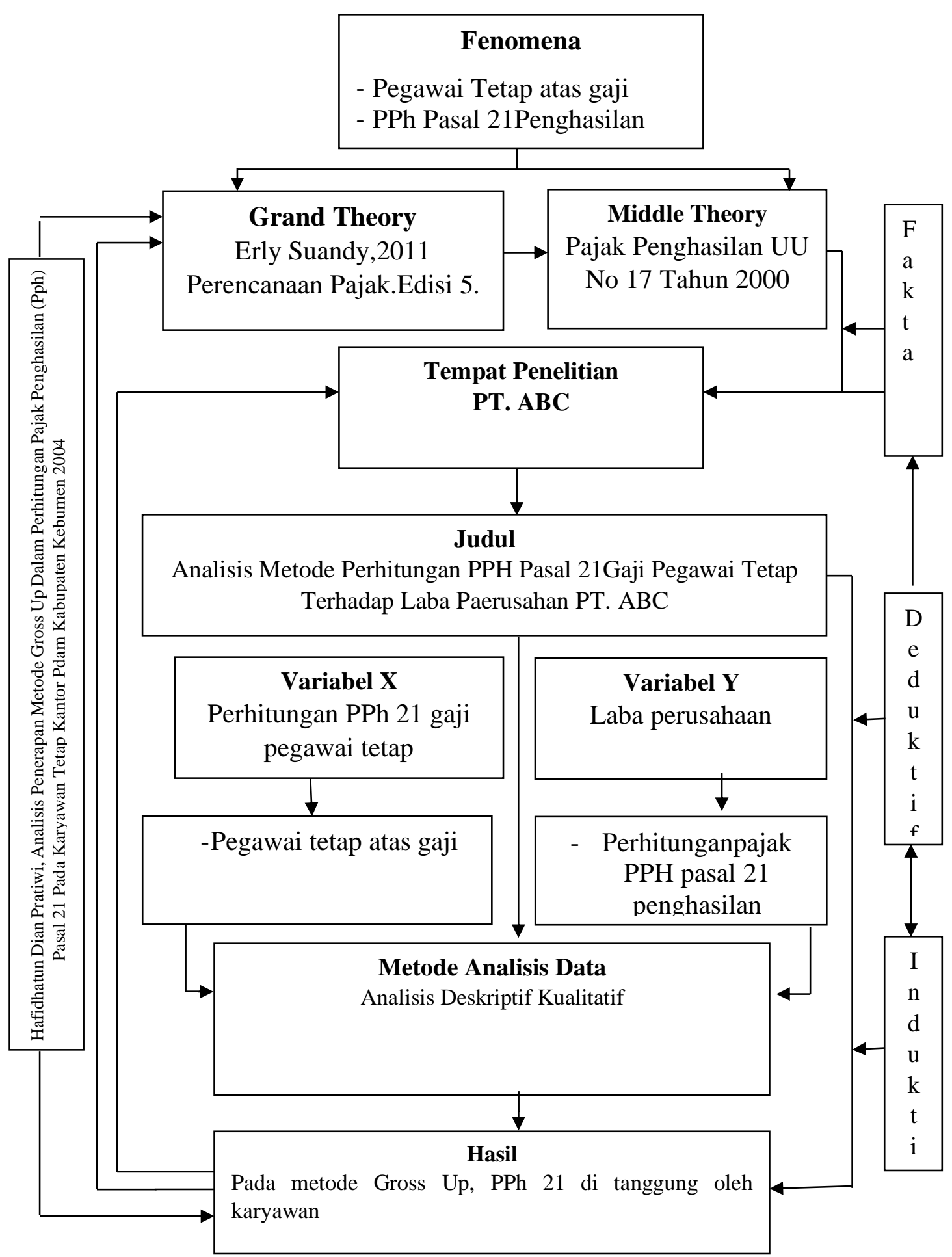

Gambar 1.1

Kerangka Pemikiran 


\section{LANDASAN TEORI}

\section{Pengertian PPh 21}

PPh 21 menurut Peraturan Direktur Jenderal (Perdirjen) Pajak Nomor PER-32/PJ/2015 adalah pajak atas penghasilan berupa gaji, upah, honorarium, tunjangan dan pembayaran lain dengan nama dan dalam bentuk apapun yang sehubungan dengan pekerjaan atau jabatan, jasa, dan kegiatan yang dilakukan oleh orang pribadi subjek pajak dalam negeri.

Wajib pajak PPh Pasal 21 adalah orang yang dikenai pajak atas penghasilannya atau penerima penghasilan yang dipotong PPh21 berdasarkan Perdirjen PER-32/PJ/2015 Pasal 3 wajib pajak PPh 21. Jika disimpulkan peserta wajib pajak terbagi menjadi 6 kategori, antara lain pegawai, bukan pegawai, penerima pensiun dan pesangon, anggota dewan komisaris, mantan pegawai dan peserta kegiatan. Secara lebih rinci peserta wajib pajak adalah sebagai berikut:

1. Pegawai;

2. Penerima uang pesangon, pensiun, atau uang manfaat pensiun, tunjangan hari tua, atau jaminan hari tua, termasuk ahli warisnya juga merupakan wajib pajak $\mathrm{PPh} 21$

3. Wajib pajak $\mathrm{PPh} 21$ kategori bukan pegawai yang menerima atau memperoleh penghasilan sehubungan dengan pemberian jasa, meliputi:

a. Tenaga ahli yang melakukan pekerjaan bebas, terdiri dari pengacara, akuntan, arsitek, dokter, konsultan, notaris, penilai dan aktuaris;

b. Pemain musik, pembawa acara, penyanyi, pelawak, bintang film, bintang sinetron, bintang iklan, sutradara, kru film, foto model, peragawan/ peragawati, pemain drama, penari, pemahat, pelukis dan seniman lain.

c. Olahragawan;

d. Penasihat, pengajar, pelatih, penceramah, penyuluh, dan moderator;

e. Pengarang, peneliti, dan penerjemah;

f. Pemberi jasa dalam segala bidang termasuk teknik, komputer dan sistem aplikasinya, telekomunikasi, elektronika, fotografi, ekonomi, dan sosial serta pemberi jasa kepada suatu kepanitiaan;

g. Agen iklan;

h. Pengawas atau pengelola proyek;

i. Pembawa pesanan atau menemukan langganan atau yang menjadi perantara;

j. Petugas penjaja barang dagangan; 
k. Petugas dinas luar asuransi; dan/atau

1. Distributor perusahaan multilevel marketing atau direct selling dan kegiatan sejenis lainnya.

4. Anggota dewan komisaris atau dewan pengawas tidak merangkap sebagai Pegawai Tetap pada perusahaan yang sama

5. Mantan pegawai; dan/atau

6. Wajib pajak PPh Pasal 21 kategori peserta kegiatan yang menerima atau memperoleh penghasilan sehubungan dengan keikutsertaannya dalam suatu kegiatan, antara lain:

a. Peserta perlombaan dalam segala bidang, antara lain perlombaan olah raga, seni, ketangkasan, ilmu pengetahuan, teknologi dan perlombaan lainnya;

b. Peserta rapat, konferensi, sidang, pertemuan, atau kunjungan kerja;

c. Peserta atau anggota dalam suatu kepanitiaan sebagai penyelenggara kegiatan tertentu;

d. Peserta pendidikan dan pelatihan; atau

e. Peserta kegiatan lainnya.

\section{Pemahaman Mengenai Dasar Pengenaan Pajak}

Apa itu Dasar Pengenaan Pajak (DPP)? Adalah dasar pengenaan pajak yang diperoleh dari penghasilan kena pajak dari wajib pajak penerima penghasilan. Apa saja DPP bagi para wajib pajak PPh 21? Berikut dasar pengenaan dan pemotongan PPh Pasal 21:

1. Penghasilan Kena Pajak (PKP), yang berlaku bagi:
a. Pegawai tetap
b. Penerima pensiun berkala
c. Pegawai tidak tetap yang penghasilannya dibayar secara bulanan atau jumlah kumulatif penghasilan yang diterima dalam satu bulan kalender telah melebihi Rp4.500.000

2. Bukan pegawai yang menerima imbalan bersifat berkesinambungan

a. Jumlah penghasilan yang melebihi Rp450.000 sehari, yang berlaku bagi pegawai tidak tetap atau tenaga kerja lepas yang menerima upah harian, upah mingguan, upah satuan atau upah borongan, sepanjang penghasilan kumulatif yang diterima dalam satu bulan kalender telah melebihi Rp4.500.000.

b. Dasar pengenaan dan pemotongan $\mathrm{PPh} 21$ selanjutnya adalah 50\% dari jumlah penghasilan bruto yang berlaku bagi bukan pegawai sebagaimana dimaksud dalam 
Perdirjen Pajak No. PER-32/PJ/2015 Pasal 3 huruf c yang menerima imbalan yang tidak bersifat berkesinambungan.

c. Jumlah penghasilan bruto yang berlaku bagi penerima penghasilan selain penerima penghasilan di atas.

\section{Tarif PPh Pasal 21}

Setelah memahami bagaimana Dasar Pengenaan Pajak (DPP) yang dijelaskan di atas, maka mengetahui berapa pajak PPh 21 yang harus dibayarkan oleh peserta wajib pajak adalah hal yang penting. Wajib pajak yang dimaksudkan di sini adalah yang memiliki Nomor Pokok Wajib Pajak (NPWP). Tarif PPh 21 dipotong dari jumlah Penghasilan Kena Pajak (PKP) yang dibulatkan ke bawah dalam ribuan penuh.

Pengenaan tarif $\mathrm{PPh}$ bersifat progresif artinya semakin tinggi penghasilan yang Anda terima atau peroleh, maka akan dikenakan lapis tarif lebih tinggi. Berikut tarif pajak PPh 21 berdasarkan Tarif Pasal 17 Undang-undang (UU) PPh:

1. Wajib Pajak dengan penghasilan tahunan sampai dengan Rp50.000.000, kena 5\%

2. Di atas Rp50.000.000 sampai dengan Rp250.000.000 kena tarif $15 \%$

3. Di atas Rp250.000.000 sampai dengan Rp500.000.000 sebesar 25\%

4. Di atas Rp 500.000.000, tarif yang dipungut sebesar $30 \%$

Namun peraturan tarif $\mathrm{PPh} 21$ bagi penerima penghasilan yang tidak memiliki NPWP seperti dikutip dari Perdirjen 32/2015, sebagai berikut:

1. Bagi penerima penghasilan yang tidak memiliki NPWP, dikenakan pemotongan PPh Pasal 21 dengan tarif lebih tinggi $20 \%$ daripada tarif yang diterapkan terhadap wajib pajak yang memiliki NPWP.

2. Jumlah PPh Pasal 21 yang harus dipotong sebagaimana yang dimaksud pada ayat (1) adalah sebesar 120\% dari jumlah PPh Pasal 21 yang seharusnya dipotong dalam hal yang bersangkutan memiliki NPWP.

3. Pemotongan PPh Pasal 21 sebagaimana dimaksud pada ayat (1) hanya berlaku untuk pemotongan PPh Pasal 21 yang bersifat tidak final.

4. Dalam hal pegawai tetap atau penerima pensiun berkala sebagai penerima penghasilan yang telah dipotong PPh Pasal 21 dengan tarif yang lebih tinggi sebagaimana dimaksud pada ayat (1) mendaftarkan diri untuk memperoleh NPWP dalam tahun kalender yang bersangkutan 
paling lama sebelum pemotongan PPh Pasal 21 untuk Masa Pajak Desember, PPh Pasal 21 yang telah dipotong atas selisih pengenaan tarif sebesar 20\% lebih tinggi tersebut diperhitungkan dengan PPh Pasal 21 yang terutang untuk bulan-bulan selanjutnya setelah memiliki NPWP.

\section{Tarif Penghasilan Tidak Kena Pajak (PTKP)}

Untuk penghasilan Anda yang dikenai Pajak Penghasilan yang bersifat tidak final, maka Anda berhak atas pengurang penghasilan neto sejumlah Penghasilan Tidak Kena Pajak (PTKP). Besarnya PTKP per tahun berdasarkan Peraturan Menteri Keuangan (PMK) Nomor 101/PMK.010/2016 tentang Penyesuaian Besarnya Penghasilan Tidak Kena Pajak adalah sebagai berikut:

1. Rp54.000.000 untuk diri Wajib Pajak orang pribadi;

2. Rp4.500.000 tambahan untuk Wajib Pajak yang kawin;

3. Rp54.000.000 tambahan untuk seorang isteri yang penghasilannya digabung dengan penghasilan suami;

4. Rp4.500.000 tambahan untuk setiap anggota keluarga sedarah dan keluarga semenda dalam garis keturunan lurus serta anak angkat, yang menjadi tanggungan sepenuhnya, paling banyak 3 orang untuk setiap keluarga.

Batasan PTKP tersebut tidak berlaku untuk:

1. Penghasilan bruto dimaksud jumlahnya melebihi Rp4.500.000 sebulan; atau

2. Penghasilan dimaksud dibayar secara bulanan

3. Penghasilan berupa honorarium

4. Komisi yang dibayarkan kepada penjaja barang dan petugas dinas luar asuransi.

Selain itu, menurut peraturan PTKP bagi karyawati atau wajib pajak wanita yang bekerja pada satu pemberi kerja, maka berlaku ketentuan sebagai berikut:

1. Bagi karyawati kawin, tarif PTKP terbaru adalah sebesar PTKP untuk dirinya sendiri;

2. Bagi karyawati tidak kawin, tarif PTKP terbaru adalah sebesar PTKP untuk dirinya sendiri ditambah PTKP untuk keluarga yang menjadi tanggungan sepenuhnya.

3. Bagi karyawati kawin yang suaminya tidak menerima atau memperoleh penghasilan dan menunjukan keterangan tertulis dari pemerintah daerah (kecamatan), maka tarif PTKP 
terbaru adalah PTKP untuk dirinya sendiri ditambah PTKP untuk status kawin dan PTKP untuk keluarga yang menjadi tanggungan sepenuhnya.

PTKP Tidak Tetap atau Tenaga kerja lepas yang tidak dibayar secara bulanan ataupun penghasilan kumulatif selama satu bulan tidak melebih Rp4.500.000, sesuai dengan peraturan PTKP, maka ketentuannya sebagai berikut:

1. Tidak dilakukan pemotongan PPh Pasal 21, jika penghasilan sehari belum melebihi Rp450.000

2. Dilakukan pemotongan $\mathrm{PPh}$ Pasal 21, jika penghasilan sehari sebesar atau melebihi Rp450.000 tersebut merupakan jumlah yang dapat dikurangkan dari penghasilan bruto;

3. Bila pegawai tidak tetap memperoleh penghasilan kumulatif dalam satu bulan kalender melebihi Rp4.500.000, maka jumlah tersebut dapat dikurangkan dari penghasilan bruto;

4. Rata-rata penghasilan sehari adalah rata-rata upah mingguan, upah satuan, atau upah borongan untuk setiap hari kerja yang digunakan.

5. PTKP sebenarnya adalah sebesar PTKP untuk jumlah hari kerja yang sebenarnya.

6. PTKP sehari sebagai dasar untuk menetapkan PTKP yang sebenarnya adalah sebesar PTKP per tahun Rp54.000.000 dibagi 360 hari.

7. Bila pegawai tidak tetap atau tenaga kerja lepas tersebut mengikuti program jaminan atau tunjangan hari tua, maka iuran yang dibayar sendiri dapat dikurangkan dari penghasilan bruto.

Bagi pegawai harian maupun tidak tetap lainnya, ketentuannya adalah sebagai berikut:

1. Penghasilan yang kurang dari Rp450.000 per hari tidak dikenakan pemotongan pajak penghasilan.

2. Ketentuan PTKP itu tidak berlaku dalam hal:

a. Penghasilan bruto dimaksud jumlahnya melebihi Rp4.500.000 sebulan; ata

b. Penghasilan dimaksud dibayar secara bulanan

3. Ketentuan pada pasal 1 dan 2 tersebut tidak berlaku atas:

a. Penghasilan berupa honorarium

b. Komisi yang dibayarkan kepada penjaja barang dan petugas dinas luar asuransi. 


\section{PPh 21 Bukan Pegawai}

Siapa yang dimaksud dengan bukan pegawai? Ya, di sini yang dimaksud bukan pegawai adalah orang pribadi selain pegawai tetap dan pegawai tidak tetap/tenaga kerja lepas yang memperoleh penghasilan dengan nama dan dalam bentuk apapun dari Pemotong PPh Pasal 21 sebagai imbalan jasa yang dilakukan berdasarkan perintah atau permintaan dari pemberi penghasilan.

Lalu bagaimanakah peraturan mengenai $\mathrm{PPh} 21$ untuk bukan pegawai? Berikut adalah pertaturan PPh 21 bagi bukan pegawai:

1. Penghasilan kena pajak atau perhitungan $\mathrm{PPh} 21$ bukan pegawai adalah sebesar $50 \%$ dari jumlah penghasilan bruto dikurangi PTKP per bulan.

2. Bila bukan pegawai tersebut memberikan jasa kepada pemotong PPh Pasal 21, maka:

Bila pemotong PPh Pasal 21 mempekerjakan orang lain sebagai pegawainya, maka besarnya jumlah penghasilan bruto adalah sebesar jumlah pembayaran setelah dikurangi dengan bagian gaji atau upah dari pegawai yang dipekerjakan tersebut, kecuali apabila dalam kontrak/perjanjian tidak dapat dipisahkan dengan bagian gaji atau upah pegawai tersebut maka besar penghasilan bruto adalah sebesar jumlah yang dibayarkan;

Bila ia hanya melakukan penyerahan material atau barang, maka besarnya jumlah penghasilan bruto hanya atas pemberian jasanya saja, kecuali apabila dalam kontrak/perjanjian tidak dapat dipisahkan antara pemberian jasa dengan material atau barang maka besarnya penghasilan bruto tersebut termasuk pemberian jasa dan material atau barang.

Lalu mungkin Anda juga bertanya-tanya, berapakah tarif pajak PPh21 bagi bukan pegawai? Berikut adalah ketentuan tarif pajak $\mathrm{PPh} 21$ yang diperuntukkan bagi bukan pegawai:

1. Tarif PPh 21 Bukan Pegawai berdasarkan Pasal 17 ayat (1) huruf a UU PPh diterapkan atas jumlah kumulatif dari:

a. Penghasilan Kena Pajak (PKP) sebesar 50\% dari jumlah penghasilan bruto dikurangi PTKP per bulan, yang diterima atau diperoleh bukan pegawai yang memenuhi ketentuan pengurangan $\mathrm{PPh} 21$ di atas. 
b. $50 \%$ dari jumlah penghasilan bruto untuk setiap pembayaran imbalan kepada bukan pegawai yang bersifat kesinambungan yang tidak memenuhi ketentuan pengurangan PPh 21 di atas.

c. Jumlah penghasilan bruto berupa honorarium atau imbalan yang bersifat tidak teratur yang diterima atau diperoleh anggota dewan komisaris atau dewan pengawas yang tidak merangkap sebagai pegawai tetap pada perusahaan yang sama.

d. Jumlah penghasilan bruto berupa jasa produksi, tantiem, gratifikasi, bonus atau imbalan lain yang bersifat tidak teratur yang diterima atau diperoleh mantan pegawai; atau

e. Jumlah penghasilan bruto berupa penarikan dana pensiun oleh peserta program pensiun yang masih berstatus sebagai pegawai, dari dana pensiun yang pendiriannya telah disahkan oleh Menteri Keuangan.

2. Tarif PPh 21 bukan pegawai berdasarkan Pasal 17 ayat (1) huruf a Undang-Undang Pajak Penghasilan diterapkan atas:

a. 50\% dari jumlah penghasilan bruto untuk setiap pembayaran imbalan kepada bukan pegawai yang tidak bersifat berkesinambungan; dan

b. Jumlah penghasilan bruto untuk setiap kali pembayaran yang bersifat utuh dan tidak dipecah, yang diterima oleh peserta kegiatan.

Selain adanya peraturan pajak PPh 21 bagi bukan pegawai, ada pula aturan untuk pengurangan pajak PPh 21 bagi bukan pegawai. Ketentuan pengurangan pajak PPh 21 bagi bukan pegawai adalah sebagai berikut:

a. Bukan pegawai dapat memperoleh pengurangan berupa PTKP sepanjang yang bersangkutan telah mempunyai NPWP dan hanya memperoleh penghasilan dari hubungan kerja dengan satu pemotong PPh Pasal 21 serta memperoleh penghasilan lainnya.

b. Untung dapat memperoleh pengurangan berupa PTKP tersebut, penerima penghasilan bukan pegawai harus menyerahkan fotokopi kartu NPWP, dan bagi wanita kawin harus menyerahkan fotokopi kartu NPWP suami, serta fotokopi surat nikah dan kartu keluarga.

Lalu bagaimanakah pajak PPh 21 bagi para dokter? Dokter yang melakukan praktik di rumah sakit dan/atau klinik, peraturannya yaitu jumlah penghasilan brutonya sebesar jasa dokter yang dibayar oleh pasien sebelum dipotong biaya-biaya atau bagi hasil oleh rumah sakit dan/atau klinik. 


\section{PPh Pasal 21 untuk Pegawai Tidak Tetap atau Pekerja Lepas}

Pegawai Tidak Tetap atau Tenaga Kerja Lepas adalah pegawai yang hanya menerima penghasilan apabila pegawai yang bersangkutan bekerja, berdasarkan jumlah hari bekerja, jumlah unit hasil pekerjaan yang dihasilkan, atau penyelesaian suatu jenis pekerjaan yang diminta oleh pemberi kerja. Di atas telah dijelaskan peraturan PTKP dengan perhitungan pajak PPh 21 bagi pegawai tidak tetap atau tenaga kerja lepas.

Lalu bagaimanakah peraturan Penghasilan Kena Pajak (PKP) dengan perhitungan pajak PPh 21 bagi pegawai tidak tetap atau tenaga kerja lepas? Secara garis besar pegawai tidak tetap atau tenaga kerja lepas yang penghasilannya kurang dari Rp450.000 tidak akan dilakukan pemotongan penghasilan. Secara lebih rinci ketentuannya adalah sebagai berikut:

1. Tarif PPh 21 pegawai tidak tetap atau tenaga kerja lepas atas penghasilan berupa upah harian, upah mingguan, upah satuan, upah borongan, dan uang saku harian, sepanjang penghasilan tidak dibayarkan secara bulanan, tarif lapisan pertama Pasal 17 ayat (1) huruf a UU Pajak Penghasilan diterapkan atas:

a. Jumlah penghasilan bruto sehari yang melebihi Rp450.000 atau

b. Jumlah penghasilan bruto dikurangi PTKP yang sebenarnya, dalam hal jumlah penghasilan kumulatif dalam satu bulan kalender telah melebihi Rp4.500.000.

2. Perhitungan $\mathrm{PPh} 21$ pegawai tidak tetap atau tenaga kerja lepas dengan jumlah penghasilan kumulatif dalam satu bulan kalender telah melebihi Rp4.500.000, PPh Pasal 21 dihitung dengan menerapkan Pasal 17 ayat 1 huruf a UU Pajak Penghasilan atas jumlah Penghasilan Kena Pajak yang disetahunkan.

\section{Gaji Karyawan Tetap}

Karena merupakan sebuah kebutuhan, saat ini banyak perusahaan yang mempekerjakan karyawan tidak tetap di perusahaannya disamping karyawan tetap tentunya. Mempekerjakan karyawan tidak tetap sudah sangat umum dilakukan oleh perusahaan-perusahaan, baik kecill, menengah maupun besar. Salah satu alasan perusahaan mempekerjakan karyawan tidak tetap adalah alasan anggaran. Dengan adanya karyawan tidak tetap, mereka bisa lebih menghemat budget karena hanya perlu menggaji karyawan saat dibutuhkan saja, selebihnya mereka tidak perlu menganggarkan anggaran gaji jika sebuah pekerjaan yang diampu karyawan tidak tetap tidak diperlukan. 
Berdasarkan Dirjen Pajak nomor 31/PJ/2009, karyawan tetap merupakan pegawai yang menerima penghasilan dalam jumlah tertentu secara teratur dan kontinue serta ikut mengelola kegiatan perusahaan secara langsung. Sedangkan karyawan tidak tetap adalah pegawai yang menerima penghasilan hanya ketika pegawai tersebut bekerja berdasarkan jumlah hari bekerja, jumlah unit hasil pekerjaan, atau penyelesaian suatu pekerjaan yang sifatnya hanya sementara. Sistem pemggajian untuk karyawan tidak tetap bisa secara bulanan maupun harian.

Meskipun lebih hemat budget, namun perusahaan perlu memikirkan masalah penggajian karyawan tidak tetap. Pasalnya, permasalahan gaji antara karyawan tetap dan karyawan tidak tetap itu berbeda. Perbedaan ini tak hanya terletak pada penerimaan dan jumlah besaran gajinya saja, melainkan terdapat perbedaan juga dari cara hitung besaran penghasilan tersebut.

Dalam menentukan besarnya gaji karyawan, perusahaan perlu mengetahui hak-hak dari karyawan terlebih dahulu. Hak-hak tersebut meliputi pemberian waktu kerja tidak lebih dari 8 jam perhari, upah yang besarnya mengikuti standar minimum UMP atau UMK, adanya cuti sakit, cuti melahirkan, dan lain sebagainya. Selain itu karyawan juga berhak memperoleh insentif atau tunjangan seperti THR, transportasi, kesehatan, serta asuransi.

Selain memperoleh hak berupa gaji, gaji karyawan tersebut aka dikenakan pungutan pajak berdasarkan pajak penghasilan $\mathrm{PPh} 21$ serta pajak badan PPh 25 yeng besarnya tergantung dari jumlah gaji yang diterima. Pajak tersebut dibayarkan secara bulanan serta tahunan yang sebaiknya dibayar tepat waktu agar terhindar dari denda yang memberatkan.

\section{Laba}

Laba adalah kenaikan modal (aktiva bersih) yang berasal dari transaksi sampingan atau transaksi yang jarang terjadi dari suatu badan usaha, dan dari semua transaksi atau kejadian lain yang mempunyai badan usaha selama satu periode, kecuali yang timbul dari pendapatan (revenue) atau investasi pemilik.

Laba sering digunakan sebagai suatu dasar untuk pengenaan pajak, kebijakan deviden, pedoman investasi serta pengambilan keputusan dan unsur prediksi.

Dalam teori ekonomi juga dikenal adanya istilah laba, akan tetapi pengertian laba di dalam teori ekonomi berbeda dengan pengertian laba menurut akuntansi. Dalam teori ekonomi, para ekonom mengartikan laba sebagai suatu kenaikan dalam kekayaan perusahaan, sedangkan dalam akuntansi, laba adalah perbedaan pendapatan yang direalisasi dari transaksi yang terjadi pada waktu dibandingkan dengan biaya-biaya yang dikeluarkan pada periode tertentu. 
Laba atau rugi sering dimanfaatkan sebagai ukuran untuk menilai prestasi perusahaan atau sebagai dasar ukuran penilaian yang lain, seperti laba per lembar saham. Unsur-unsur yang menjadi bagian pembentuk laba adalah pendapatan dan biaya. Dengan mengelompokkan unsurunsur pendapatan dan biaya, akan dapat diperoleh hasil pengukuran laba yang berbeda antara lain: laba kotor, laba operasional, laba sebelum pajak, dan laba bersih.

Pengukuran laba bukan saja penting untuk menentukan prestasi perusahaan tetapi penting juga penting sebagai informasi bagi pembagian laba dan penentuan kebijakan investasi. Oleh karena itu, laba menjadi informasi yang dilihat oleh banyak seperti profesi akuntansi, pengusaha, analis keuangan, pemegang saham, ekonom, fiskus, dan sebagainya.

\section{METODOLOGI PENELITIAN}

\section{Ruang Lingkup Penelitian}

Pada penulisan penelitian ini, yang akan dijadikan objek studi penelitian oleh penulis adalah PT. ABC yang beralamat di Graha Mandiri Jl. Imam Bonjol No. 61 Lt. 9 Jakarta Pusat. Ruang lingkup penelitian yang dilakukan penulis hanya dibatasi pada seberapa besar analisa metode perhitungan Pajak Penghasilan Pasal 21 terhadap laba perusahan pada PT. ABC.

\section{Penentuan Populasi dan Sampel}

1. Populasi

Populasi merupakan sekumpulan orang atau objek yang memiliki kesamaan dalam satu atau beberapa hal dan yang membentuk masalah pokok dalam suatu riset khusus. Populasi yang akan diteliti harus didefinisikan dengan jelas sebelum penelitian dilakukan (Santoso dan Tjiptono, 2002:79).Dalam penelitian ini penulis menggunakan sampel pada PT. ABC salah satu PT yang terdapat Di Graha Mandiri Jl. Imam Bonjol No. 61 dengan menggunakan data time series selama 1 tahun. Data time seies adalah sekumpulan data dari suatu fenomena tertentu yang didapat dalam suatu interval waktu tertentu misalnya dalam waktu mingguan, bulanan, atau tahunan dan tidak boleh ada data yang hilang dari tahun-tahun tersebut (Husein, 2008:42). 
2. Sampel

Sampel adalah sebagian atau wakil populasi yang diteliti (Arikunto, 2002:109). Dalam penelitian, penelitian dapat menjadikan seluruh obyek atau populasi untuk diteliti tetapi dapat juga mengambil sebagian saja dari keseluruhan objek penelitian untuk diteliti.

Kriteria yang digunakan untuk memilih sampel adalah sebagai berikut:
a. Laporan Laba rugi Per Desember 2014
b. Neraca
c. Daftar Gaji karyawan
d. Daftar Perhitungan Pajak Penghasilan 21

\section{Metode Pengumpulan Data}

Untuk mendapatkan informasi dan data dalam penyusunan penelitian ini, penulisan menggunakan beberapa metode pengumpulan data, yaitu:

1. Studi Kepustakan

Untuk mendapatkan landasan dan konsep yang kuat agar dapat memecahkan permasalahan, penulisan mengadakan penelitian keputusan dengan mengumpulkan data-data yang di perlukan dari literatur, media cetak, dan lain-lain yang berhubungan dengan topik penelitian.

2. Penelitian Lapangan

Yaitu metode penelitian yang di lakukan langsung ke perusahan yang di teliti untuk mendapatkan informasi yang lebih otentik secara nyata selain dari penelitian keperpustakan, metode ini di lakukan dengan cara:

a. Observasi langsung

Dilakukan langsung ke lapangan untuk meneliti metode perhitungan Pajak Penghasilan Pasal 21 dan laporan laba rugi perusahan.

b. Sumber data

Data-data dalam penelitian diperolehan langsung dari PT ABC.Pada penelitian ini penulisan mengumpulkan data perhitungan Pajak Penghasilan Pasal 21 Januari dengan Maret 2014 dan laporan laba rugi tahun 2014. 


\section{Metode Analisis}

Sesuai dengan masalah penelitian yang ada, yaitu untuk mengetahui metode perhitungan Pajak Penghasilan Pasal 21 pegawai tetap terhadap laba perusahan PT.ABC, maka penulisan menggunakan 2 metode analisis yaitu:

1. Analisa kualitatif, yaitu analisa dengan cara mempelajari dalam menguji apakah ketentuanketentuan yang berlaku telah ditetapkan oleh perusahan.

2. Analisa kuantitatif, yaitu analisa atas hasil penelitian dengan menggunakan perhitungan angka-angka.

\section{Operasional Variabel Penelitian}

Berkaitan dengan judul penelitian ini, maka perlu diberikan definisi dari konsep-konsep dalam judul agar dapat persamaan persepsi.

Hal-hal yang berhubungan dengan judul dalam penelitian ini adalah:

1. Perhitungan Pajak Penghasilan Pasal 21 adalah perhitungan pajak bagi penerima-penerima penghasilan dari pekerjaan, jasa atau kegiatan yang dilakukan Wajib Pajak Orang Pribadi yaitu Wajib Pajak dalam negeri selain berupa PTKP, juga diberikan penguranganpengurangan penghsailan berupa biaya jabatan, biaya pensiun dan iuran pensiun.

2. Pegawai adalah setiap orang pribadi yang melakukan pekerjan berdasarkan perjanjian atau kesempatan kerja baik tertulis maupun tidak, termasuk yang melakukan perjakan di BUMN/BUMD.

3. Pegawai Tetap adalah orang pribadi yang bekerja pada pemberi kerja yang menerima atau memperoleh gaji dalam jumlah tertentu secara berkala, termasuk angota dewan komisaris, dan anggota dewanpengawas yang secarar teratur terus menerus ikut mengelola perusahan secara langsung.

4. Laba adalah kelebihan dari pendapatan melebihi biaya untuk satu periode akuntansi.

5. Rugi adalah penurunan nilai modal yang merupakan hasil dari operasi suatu usaha. Hal ini terjadi karena beban-beban operasi lebih besar nilainya dari pada pendapatan dalam satu periode akuntansi.

6. laporan laba rugi adalah laporan tentang komposisi penjualan, harga pokok, dan biaya-biaya perusahan selama suatu periode tertentu. 


\section{HASIL PENELITIN DAN PEMBAHASAN}

\section{Gambaran Umum PT. ABC.}

\section{Sejarah Singkat PT. ABC}

Perusahan ini didirikan pada tanggal 11 Agustus 1982. Perusahan berkedudukan di Graha Mandiri Jl. Imam Bonjol No. 61 Jakarta 10310, Jakarta Pusat. Perusahan ini bergerak di bidang Broker \& Consultants Asuransi yang sudah berpengalaman. Dengan mayoritas saham dipegang oleh Yayasan Kesejahteraan Bumi Daya \& Dana Pensiun Bank Mandiri Satu. Alamat Kantor berlokasi di 9 (sembilan) kota besar di Indonesia.

\section{Visi dan Misi PT. ABC}

a. Visi

“Kepuasan pelanggan, keberhasilan kami”

b. Misi

1) Memberikan produk dan layanan asuransi yang berkulitas tinggi, di lengkapi dengan proteksi yang berkelas, premi yang wajar dan pelayanan klaim yang cepat

2) Memperkerjakan karyawan yang prefisional dan kreatif untuk meninggkatkan efisiensi perusahaan kami,

3) Mengelola perusahan kami berdasarkan sasaran, bukan petunjuk.

\section{Prosedur Pelaksanaan Perhitungan PPh Pasal 21 Gaji Pegawai pada PT. ABC.}

Dalam menghitung pajak penghasilan pasal 21 terdapat beberapa metode :

1. Metode Ditanggung oleh Karyawan, merupakan metode dimana pajak penghasilan ditanggung oleh pegawai, sehingga pada saat pegawai menerima penghasilan, pajak penghasilan pasal 21 sudah langsung diperhitungkan dan dipotong dari penghasilan yang diterima oleh pegawai.

2. Metode Ditanggung oleh Perusahaan, merupakan metode dimana pajak penghasilan pasal 21 ditanggung oleh perusahaan, sehingga pada saat pegawai menerima penghasilan tidak diperhitungkan dan dipotong pajak penghasilan pasal 21. Terkait dengan metode ini pajak 
penghasilan pasal 21 yang dibayarkan oleh perusahaan bukan merupakan biaya, sehingga harus dilakukan koreksi fiskal positf dalam menghitung besarnya Pajak Penghasilan Badan.

Berikut penulis lampirkan perhitungan di perusahaan:

a. Cara Perhitungan Nett

Tn. A

Gaji Rp. 570.000 .000

Tunj. Pajak

Rp. 570.000 .000

Penghasilan Bruto

Pengurangan:

Bi. Jabatan:

Rp. 28.500 .000

Bi. Iuran Pensiun:

Rp. $11.400 .000+$

Penghasilan Netto

Rp. 530.100 .000

PTKP:

Rp. $28.350 .000-$

Rp. $39.900 .000-$

Penghasilan Kena Pajak

Rp. 501.750 .000

PPh 21

Rp. 95.525 .000

Tax Home Pay

Rp. 474.475.000

b. Cara perhitungan Gross Up

Gaji

Rp. 570.000 .000

Tunj. Pajak

Rp. 133. 601.399

Penghasilan Bruto

Rp. 703.601 .399

Pengurangan:

Bi. Jabatan:

Rp. 35.180 .070

Bi. Iuran Pensiun:

Rp. $11.400 .000+$

Penghasilan Netto

PTKP:

Penghasilan Kena Pajak

Rp. $46.580 .070-$

Rp. 657.021 .329

Rp. $28.350 .000-$

Rp. 628.671.329

PPh 21

Rp. 133.601.399

Tax Home Pay

Rp. 570.000.000 
Tabel 4.1

Daftar Perhitungan Pajak Penghasilan Pasal 21

TABEL PERHITUNGAN PPH PASAL 21 DENGAN CARA GROOS UP

\begin{tabular}{|c|c|c|c|c|c|c|c|c|c|c|c|c|c|c|}
\hline \multirow{2}{*}{ NO } & \multirow{2}{*}{ NAMA } & \multirow{2}{*}{ STATUS } & \multicolumn{4}{|c|}{ PENGHASILAN } & \multicolumn{3}{|c|}{ PENGURANG } & \multirow{2}{*}{$\begin{array}{l}\text { JUMLAH } \\
\text { PH.NETO }\end{array}$} & \multirow{2}{*}{ PTKP } & \multirow{2}{*}{$\begin{array}{l}\text { PENGH. } \\
\text { KENA PJK }\end{array}$} & \multirow{2}{*}{$\begin{array}{c}\text { PPH } \\
\text { PSL } 21\end{array}$} & \multirow{2}{*}{$\begin{array}{c}\text { TAHE } \\
\text { HOME PAY }\end{array}$} \\
\hline & & & PER BLN & GAII & T.PAJAK & JUMLAH & BI.JAB & JRAN PENSIU & JUMLAH & & & & & \\
\hline 1 & A & $k / 1$ & 47.500 .000 & 570.000 .000 & 133.601 .399 & 703.601.399 & 35.180 .070 & 11.400 .000 & 46.580 .070 & 657.021 .329 & 28.350 .000 & 628.671 .329 & 133.601.399 & 558.600 .000 \\
\hline 2 & B & $k / 1$ & 45.000 .000 & 540.000 .000 & 121.895 .105 & 661.895 .105 & 3.094 .755 & 10.800 .000 & 43.894 .755 & 618.000 .350 & 28.350 .000 & 589.650 .350 & 121.895 .105 & 529.200 .000 \\
\hline 3 & C & $\mathrm{k} / 2$ & 30.000 .000 & 360.000 .000 & 60.467 .213 & 420.467 .213 & 21.023 .361 & 7.200 .000 & 28.223.361 & 392.243 .852 & 30.375 .000 & 361.868 .852 & 60.467 .213 & 352.800 .000 \\
\hline 4 & D & $k / 2$ & 27.500 .000 & 330.000 .000 & 51.319 .672 & 381.319 .672 & 19.065 .984 & 600.000 & 25.665 .984 & 355.653 .689 & 30.375 .000 & 325.278 .689 & 51.319 .672 & 323.400 .000 \\
\hline 5 & $E$ & $k / 2$ & 25.000 .000 & 300.000 .000 & 42.172 .131 & 342.172 .131 & 17.108 .607 & 6.000 .000 & 23.108 .607 & 319.063 .525 & 30.375 .000 & 288.688 .525 & 42.172 .131 & 294.000 .000 \\
\hline 6 & $\mathrm{~F}$ & $k / 2$ & 20.000 .000 & 240.000 .000 & 27.899 .417 & 267.899 .417 & 13.394 .971 & 4.800 .000 & 18.194 .971 & 249.704 .446 & 30.375 .000 & 219.329 .446 & 27.899 .417 & 235.200 .000 \\
\hline 7 & G & $k / 1$ & 20.000 .000 & 240.000 .000 & 28.253 .644 & 268.253 .644 & 13.412 .682 & 4.800 .000 & 18.212 .682 & 250.040 .962 & 28.350 .000 & 221.690 .962 & 28.253 .644 & 235.200 .000 \\
\hline 8 & $\mathrm{H}$ & $\mathrm{k} / 0$ & 15.000 .000 & 180.000 .000 & 18.846 .939 & 198.846 .939 & 9.942 .347 & 3.600 .000 & 13.542 .347 & 185.304 .592 & 26.325 .000 & 158.979 .592 & 18.846 .939 & 176.400 .000 \\
\hline 9 & 1 & $\mathrm{Tk} / 0$ & 15.000 .000 & 180.000 .000 & 19.201 .166 & 199.201 .166 & 9.960 .058 & 3.600 .000 & 13.560 .058 & 185.641 .108 & 24.300 .000 & 161.341 .108 & 19.201 .166 & 176.400 .000 \\
\hline 10 & $\mathrm{~J}$ & TK/0 & 15.000 .000 & 180.000 .000 & 19.201.166 & 199.201 .166 & 9.960 .058 & 3.600 .000 & 13.560 .058 & 185.641 .108 & 24.300 .000 & 161.341 .108 & 19.201 .166 & 176.400 .000 \\
\hline 11 & $\mathrm{~K}$ & $\mathrm{k} / 1$ & 5.000 .000 & 60.000 .000 & 1.440 .945 & 61.440 .945 & 3.072 .047 & & 4.272 .047 & 57.168 .898 & 28.350 .000 & 28.818 .898 & 1.440 .945 & 58.800 \\
\hline 12 & $L$ & $k / 0$ & 5.000 .000 & 60.000 .000 & & 61.547 .244 & 3.077 .362 & & 4.277 .362 & .269 .882 & & 944.882 & 1.547 .244 & 000 \\
\hline 13 & $M$ & Tk/0 & 5.000 .000 & 60.000 .000 & 1.653 .543 & 61.653 .543 & 82.677 & 000 & 4.282 .677 & 57.370 .866 & 24.300 .000 & 33.070 .866 & 1.653 .543 & 58.800 .000 \\
\hline 14 & $\mathrm{~N}$ & $\mathrm{k} / 1$ & 5.000 .000 & 60.000 .000 & 1.440 .945 & 61.440 .945 & 972.047 & 200.000 & 4.272 .047 & 57.168 .898 & 28.350 .000 & 28.818 .898 & 1.440 .945 & 58.800 .000 \\
\hline 15 & $\mathrm{O}$ & $k / 2$ & 5.000 .000 & 60.000 .000 & 334.646 & 61.334 .646 & 66.732 & 200.000 & 4.266 .732 & 57.067 .913 & 30.375 .000 & 26.692 .913 & 1.334 .646 & 8.800 .000 \\
\hline 16 & $\mathrm{P}$ & $k / 1$ & 5.000 .000 & 60.00 & 40.945 & 61.440 .945 & 2.047 & 200.000 & 4.272 .047 & 57.168 .898 & 28.350 .000 & 28.818 .898 & 1.440 .945 & 00.000 \\
\hline 17 & Q & $\mathrm{Tk} / 0$ & 5.000 .000 & 60.000 .000 & .653 .543 & 61.653 .543 & 32.677 & 200.000 & 4.282 .677 & 57.370 .866 & 24.300 .000 & 33.070 .866 & 1.653 .543 & 00.000 \\
\hline 18 & $\mathrm{R}$ & $\mathrm{Tk} / 0$ & 5.000 .000 & 60.000 .000 & 1.653 .543 & 61.653 .543 & 3.082 .677 & 1.200 .000 & 4.282 .677 & 57.370 .866 & 24.300 .000 & 33.070 .866 & 1.653 .543 & 58.800 .000 \\
\hline 19 & $S$ & $k / 1$ & 5.000 .000 & 60.000 .000 & 1.440 .945 & 61.440 .945 & 3.072 .047 & 1.200 .000 & 4.272 .047 & 57.168 .898 & 28.350 .000 & 28.818 .898 & 1.440 .945 & 58.800 .000 \\
\hline 20 & $\mathrm{~T}$ & $\mathrm{~K} / 0$ & 5.000 .000 & 60.000 .000 & 1.547 .244 & 61.547 .244 & 3.077 .362 & 1.200 .000 & 4.277 .362 & 57.269 .882 & 26.325 .000 & 30.944 .882 & 1.547 .244 & 58.800 .000 \\
\hline 21 & $U$ & $\mathrm{~K} / 2$ & 5.000 .000 & 60.000 .000 & 1.334 .646 & 61.334 .646 & 3.066 .732 & 1.200 .000 & 4.266 .732 & 57.067 .913 & 30.375 .000 & 26.692 .913 & 1.334 .646 & 58.800 .000 \\
\hline 22 & V & $\mathrm{K} / 1$ & 5.000 .000 & 60.000 .000 & 1.440 .945 & 61.440 .945 & 3.072 .047 & 1.200 .000 & 4.272 .047 & 57.168 .898 & 28.350 .000 & 28.818 .898 & 1.440 .945 & 58.800 .000 \\
\hline 23 & W & $\mathrm{K} / 1$ & 5.000 .000 & 60.000 .000 & 1.440 .945 & 61.440 .945 & 3.072 .047 & 1.200 .000 & 4.272 .047 & 57.168 .898 & 28.350 .000 & 28.818 .898 & 1.440 .945 & 58.800 .000 \\
\hline 24 & $x$ & $\mathrm{~K} / \mathrm{O}$ & 3.000 .000 & 36.000 .000 & 375.591 & 36.375 .591 & 1.818 .780 & 720.000 & 2.538 .780 & 33.836 .811 & 26.325 .000 & 7.511 .811 & 375.591 & 35.280 .000 \\
\hline 25 & $Y$ & TK/0 & 3.000 .000 & 36.000 .000 & 481.890 & 36.481 .890 & 1.824 .094 & 720.000 & 2.544 .094 & 33.937 .795 & 24.300 .000 & 9.637 .795 & 481.890 & 35.280 .000 \\
\hline 26 & $Z$ & $\mathrm{~K} / 0$ & 2.800 .000 & 33.600 .000 & 258.425 & 33.858 .425 & 1.692 .921 & 672.000 & 2.364 .921 & 31.493 .504 & 26.325 .000 & 5.168 .504 & 258.425 & 32.928 .000 \\
\hline 27 & AA & $\mathrm{K} / 1$ & 2.800 .000 & 33.600 .000 & 152.126 & 33.752 .126 & 1.687 .606 & 672.000 & 2.359 .606 & 31.392 .520 & 28.350 .000 & 3.042 .520 & 152.126 & 32.928 .000 \\
\hline 28 & $A B$ & $\mathrm{~K} / 2$ & 2.800 .000 & 33.600 .000 & 45.827 & 33.645 .827 & 1.682 .291 & 672.000 & 2.354 .291 & 31.291 .535 & 30.375 .000 & 916.535 & 45.827 & 32.928 .000 \\
\hline 29 & $\mathrm{AC}$ & $\mathrm{K} / 2$ & 2.800 .000 & 33.600 .000 & 45.827 & 33.645 .827 & 1.682 .291 & 672.000 & 2.354 .291 & 31.291 .535 & 30.375 .000 & 916.535 & 45.827 & 32.928 .000 \\
\hline
\end{tabular}


Tabel 4.2

Daftar Perhitungan Pajak Penghasilan Pasal

TABEL PERHITUNGAN PPH PASAL 21 DENGAN CARA DIPOTONG

\begin{tabular}{|c|c|c|c|c|c|c|c|c|c|c|c|c|c|c|}
\hline \multirow{2}{*}{ NO } & \multirow{2}{*}{ NAMA } & \multirow{2}{*}{ STATUS } & \multicolumn{4}{|c|}{ PENGHASILAN } & \multicolumn{3}{|c|}{ PENGURANG } & \multirow{2}{*}{$\begin{array}{l}\text { JUMLAH } \\
\text { PH.NETO }\end{array}$} & \multirow{2}{*}{ PTKP } & \multirow{2}{*}{$\begin{array}{l}\text { PENGH. } \\
\text { KENA PJK }\end{array}$} & \multirow{2}{*}{$\begin{array}{c}\text { PPH } \\
\text { PSL } 21\end{array}$} & \multirow{2}{*}{$\begin{array}{c}\text { TAHE } \\
\text { HOME PAY }\end{array}$} \\
\hline & & & GAJI/BLN & GAII & T.PAJAK & JUMLAH & BI.JAB & IURAN PENSIUN & JUMLAH & & & & & \\
\hline 1 & A & $\mathrm{k} / 1$ & 47.500 .000 & 570.000 .000 & - & 570.000 .000 & 28.500 .000 & 11.400 .000 & 39.900 .000 & 530.100 .000 & 28.350 .000 & 501.750 .000 & 95.525 .000 & 463.075 .000 \\
\hline 2 & B & $\mathrm{k} / 1$ & 45.000 .000 & 540.000 .000 & - & 540.000 .000 & 27.000 .000 & 10.800 .000 & 37.800 .000 & 502.200 .000 & 28.350 .000 & 473.850 .000 & 88.462 .500 & 440.737 .500 \\
\hline 3 & C & $\mathrm{k} / 2$ & 30.000 .000 & 360.000 .000 & - & 360.000 .000 & 18.000 .000 & 7.200 .000 & 25.200 .000 & 334.800 .000 & 30.375 .000 & 304.425 .000 & 46.106 .250 & 306.693 .750 \\
\hline 4 & $\mathrm{D}$ & $\mathrm{k} / 2$ & 27.500 .000 & 330.000 .000 & - & 330.000 .000 & 16.500 .000 & 6.600 .000 & 23.100 .000 & 306.900 .000 & 30.375 .000 & 276.525 .000 & 39.131 .250 & 284.268 .750 \\
\hline 5 & E & $\mathrm{k} / 2$ & 25.000 .000 & 300.000 .000 & - & 300.000 .000 & 15.000 .000 & 6.000 .000 & 21.000 .000 & 279.000 .000 & 30.375 .000 & 248.625 .000 & 32.293 .750 & 261.706 .250 \\
\hline 6 & $\mathrm{~F}$ & $\mathrm{k} / 2$ & 20.000 .000 & 240.000 .000 & - & 240.000 .000 & 12.000 .000 & 4.800 .000 & 16.800 .000 & 223.200 .000 & 30.375 .000 & 192.825 .000 & 23.923 .750 & 211.276 .250 \\
\hline 7 & $G$ & $\mathrm{k} / 1$ & 20.000 .000 & 240.000 .000 & - & 240.000 .000 & 12.000 .000 & 4.800 .000 & 16.800 .000 & 223.200 .000 & 28.350 .000 & 194.850 .000 & 24.227 .500 & 210.972 .500 \\
\hline 8 & $\mathrm{H}$ & $\mathrm{k} / 0$ & 15.000 .000 & 180.000 .000 & - & 180.000 .000 & 9.000 .000 & 3.600 .000 & 12.600 .000 & 167.400 .000 & 26.325 .000 & 141.075 .000 & 16.161 .250 & 160.238 .750 \\
\hline 9 & 1 & $\mathrm{Tk} / 0$ & 15.000 .000 & 180.000 .000 & - & 180.000 .000 & 9.000 .000 & 3.600 .000 & 12.600 .000 & 167.400 .000 & 24.300 .000 & 143.100 .000 & 16.465 .000 & 159.935 .000 \\
\hline 10 & $\mathrm{~J}$ & TK/0 & 15.000 .000 & 180.000 .000 & - & 180.000 .000 & 9.000 .000 & 3.600 .000 & 12.600 .000 & 167.400 .000 & 24.300 .000 & 143.100 .000 & 16.465 .000 & 159.935 .000 \\
\hline 11 & $\mathrm{~K}$ & $\mathrm{k} / 1$ & 5.000 .000 & 60.000 .000 & - & 60.000 .000 & 3.000 .000 & 1.200 .000 & 4.200 .000 & 55.800 .000 & 28.350 .000 & 27.450 .000 & 1.372 .500 & 57.427 .500 \\
\hline 12 & $\mathrm{~L}$ & $\mathrm{k} / 0$ & 5.000 .000 & 60.000 .000 & - & 60.000 .000 & 3.000 .000 & 1.200 .000 & 4.200 .000 & 55.800 .000 & 26.325 .000 & 29.475 .000 & 1.473 .750 & 57.326 .250 \\
\hline 13 & $M$ & Tk/0 & 5.000 .000 & 60.000 .000 & - & 60.000 .000 & 3.000 .000 & 1.200 .000 & 4.200 .000 & 55.800 .000 & 24.300 .000 & 31.500 .000 & 1.575 .000 & 57.225 .000 \\
\hline 14 & $\mathrm{~N}$ & $\mathrm{k} / 1$ & 5.000 .000 & 60.000 .000 & - & 60.000 .000 & 3.000 .000 & 1.200 .000 & 4.200 .000 & 55.800 .000 & 28.350 .000 & 27.450 .000 & 1.372 .500 & 57.427 .500 \\
\hline 15 & 0 & $\mathrm{k} / 2$ & 5.000 .000 & 60.000 .000 & - & 60.000 .000 & 3.000 .000 & 1.200 .000 & 4.200 .000 & 55.800 .000 & 30.375 .000 & 25.425 .000 & 1.271 .250 & 57.528 .750 \\
\hline 16 & $\mathrm{P}$ & $\mathrm{k} / 1$ & 5.000 .000 & 60.000 .000 & - & 60.000 .000 & 3.000 .000 & 1.200 .000 & 4.200 .000 & 55.800 .000 & 28.350 .000 & 27.450 .000 & 1.372 .500 & 57.427 .500 \\
\hline 17 & Q & $\mathrm{Tk} / 0$ & 5.000 .000 & 60.000 .000 & - & 60.000 .000 & 3.000 .000 & 1.200 .000 & 4.200 .000 & 55.800 .000 & 24.300 .000 & 31.500 .000 & 1.575 .000 & 57.225 .000 \\
\hline 18 & $\mathrm{R}$ & $\mathrm{Tk} / 0$ & 5.000 .000 & 60.000 .000 & - & 60.000 .000 & 3.000 .000 & 1.200 .000 & 4.200 .000 & 55.800 .000 & 24.300 .000 & 31.500 .000 & 1.575 .000 & 57.225 .000 \\
\hline 19 & S & $\mathrm{k} / 1$ & .000 & 60.000 .000 & - & 60.000 .000 & 3.000 .000 & 1.200 .000 & 4.200 .000 & 55.800 .000 & 28.350 .000 & 27.450 .000 & 1.372 .500 & 57.427 .500 \\
\hline 20 & $T$ & $\mathrm{~K} / 0$ & 5.000 .000 & 60.000 .000 & - & 60.000 .000 & 3.000 .000 & 1.200 .000 & 4.200 .000 & 55.800 .000 & 26.325 .000 & 29.475 .000 & 1.473 .750 & 57.326 .250 \\
\hline 21 & $U$ & $\mathrm{~K} / 2$ & 5.000 .000 & 60.000 .000 & - & 60.000 .000 & 3.000 .000 & 1.200 .000 & 4.200 .000 & 55.800 .000 & 30.375 .000 & 25.425 .000 & 1.271 .250 & 57.528 .750 \\
\hline 22 & V & $\mathrm{K} / 1$ & 5.000 .000 & 60.000 .000 & - & 60.000 .000 & 3.000 .000 & 1.200 .000 & 4.200 .000 & 55.800 .000 & 28.350 .000 & 27.450 .000 & 1.372 .500 & 57.427 .500 \\
\hline 23 & W & $\mathrm{K} / 1$ & 5.000 .000 & 60.000 .000 & - & 60.000 .000 & 3.000 .000 & 1.200 .000 & 4.200 .000 & 55.800 .000 & 28.350 .000 & 27.450 .000 & 1.372 .500 & 57.427 .500 \\
\hline 24 & $x$ & $\mathrm{~K} / 0$ & 3.000 .000 & 36.000 .000 & - & 36.000 .000 & 1.800 .000 & 720.000 & 2.520 .000 & 33.480 .000 & 26.325 .000 & 7.155 .000 & 357.750 & 34.922 .250 \\
\hline 25 & $\mathrm{Y}$ & TK/0 & 3.000 .000 & 36.000 .000 & - & 36.000 .000 & 1.800 .000 & 720.000 & 2.520 .000 & 33.480 .000 & 24.300 .000 & 9.180 .000 & 459.000 & 34.821 .000 \\
\hline 26 & Z & $\mathrm{K} / 0$ & 2.800 .000 & 33.600 .000 & - & 33.600 .000 & 1.680 .000 & 672.000 & 2.352 .000 & 31.248 .000 & 26.325 .000 & 4.923 .000 & 246.150 & 32.681 .850 \\
\hline 27 & AA & $\mathrm{K} / 1$ & 2.800 .000 & 33.600 .000 & - & 33.600 .000 & 1.680 .000 & 672.000 & 2.352 .000 & 31.248 .000 & 28.350 .000 & 2.898 .000 & 144.900 & 32.783 .100 \\
\hline 28 & $A B$ & $\mathrm{~K} / 2$ & 2.800 .000 & 33.600 .000 & 8 & 33.600 .000 & 1.680 .000 & 672.000 & 2.352 .000 & 31.248 .000 & 30.375 .000 & 873.000 & 43.650 & 32.884 .350 \\
\hline 29 & $A C$ & $\mathrm{~K} / 2$ & 2.800 .000 & 33.600 .000 & - & 33.600 .000 & 1.680 .000 & 672.000 & 2.352 .000 & 31.248 .000 & 30.375 .000 & 873.000 & 43.650 & 32.884 .350 \\
\hline \multicolumn{3}{|c|}{ JUMLAH } & 342.200 .000 & 4.106 .400 .000 & - & 4.106 .400 .000 & 205.320 .000 & 82.128 .000 & 287.448 .000 & 3.818 .952 .000 & 803.925 .000 & 3.015 .027 .000 & 418.506 .350 & 3.605 .765 .650 \\
\hline
\end{tabular}




\section{Penyebab Metode Perhitungan Pph Pasal 21 Pada Tingkat Laba Perusahaan Masih Fluktuasi}

Didalam perhitungan Pajak Penghasilan Pasal 21 PT. ABC, tunjangan-tunjangan yang diberikan kepada setiap pegawai tetap PT.ABC setiap bulan yang besarnya sesuai dengan peringkat jabatan masing-masing pegawai. Dalam menghitung Pajak Penghasilan Pasal 21 gaji pegawai yang bersangkutan, tunjangan pajak tergantung pada penghasilan yang diterima sehingga tunjangan pajak tersebut mempengaruhi tingkat laba perusahaan.

Dibawah ini penulis lampirkan Daftar Penghasilan Karyawan.

Tabel 4.3

Daftar Penghasilan Karyawan

\begin{tabular}{|c|c|c|c|c|}
\hline No. & NAMA & JABATAN & STATUS & GAJI \\
\hline 1 & A & Direktur Utama & $\mathrm{k} / 1$ & 47.500 .000 \\
\hline 2 & B & Direktur & $\mathrm{k} / 1$ & 45.000 .000 \\
\hline 3 & $\mathrm{C}$ & Komisaris Utama & $\mathrm{k} / 2$ & 30.000 .000 \\
\hline 4 & $\mathrm{D}$ & Komisaris & $\mathrm{k} / 2$ & 27.500 .000 \\
\hline 5 & $\mathrm{E}$ & General Manager & $\mathrm{k} / 2$ & 25.000 .000 \\
\hline 6 & $\mathrm{~F}$ & Senior Manager & $\mathrm{k} / 2$ & 20.000 .000 \\
\hline 7 & $\mathrm{G}$ & Senior Manager & $\mathrm{k} / 1$ & 20.000 .000 \\
\hline 8 & $\mathrm{H}$ & Manager & $\mathrm{k} / 0$ & 15.000 .000 \\
\hline 9 & I & Manager & $\mathrm{Tk} / 0$ & 15.000 .000 \\
\hline 10 & $\mathrm{~J}$ & Manager & TK/0 & 15.000 .000 \\
\hline 11 & $\mathrm{~K}$ & Staff & $\mathrm{k} / 1$ & 5.000 .000 \\
\hline 12 & $\mathrm{~L}$ & Staff & $\mathrm{k} / 0$ & 5.000 .000 \\
\hline 13 & M & Staff & $\mathrm{Tk} / 0$ & 5.000 .000 \\
\hline 14 & $\mathrm{~N}$ & Staff & $\mathrm{k} / 1$ & 5.000 .000 \\
\hline 15 & $\mathrm{O}$ & Staff & $\mathrm{k} / 2$ & 5.000 .000 \\
\hline 16 & $\mathrm{P}$ & Staff & $\mathrm{k} / 1$ & 5.000 .000 \\
\hline 17 & $\mathrm{Q}$ & Staff & $\mathrm{Tk} / 0$ & 5.000 .000 \\
\hline 18 & $\mathrm{R}$ & Staff & $\mathrm{Tk} / 0$ & 5.000 .000 \\
\hline 19 & $S$ & Staff & $\mathrm{k} / 1$ & 5.000 .000 \\
\hline 20 & $\mathrm{~T}$ & Staff & $\mathrm{K} / 0$ & 5.000 .000 \\
\hline 21 & $\mathrm{U}$ & Staff & $\mathrm{K} / 2$ & 5.000 .000 \\
\hline 22 & $\mathrm{~V}$ & Staff & $\mathrm{K} / 1$ & 5.000 .000 \\
\hline 23 & $\mathrm{~W}$ & Staff & $\mathrm{K} / 1$ & 5.000 .000 \\
\hline 24 & $\mathrm{X}$ & Non Staff & $\mathrm{K} / 0$ & 3.000 .000 \\
\hline 25 & $\mathrm{Y}$ & Non Staff & $\mathrm{TK} / 0$ & 3.000 .000 \\
\hline 26 & $\mathrm{Z}$ & Non Staff & $\mathrm{K} / 0$ & 2.800 .000 \\
\hline 27 & AA & Non Staff & $\mathrm{K} / 1$ & 2.800 .000 \\
\hline 28 & $\mathrm{AB}$ & Non Staff & $\mathrm{K} / 2$ & 2.800 .000 \\
\hline 29 & $\mathrm{AC}$ & Non Staff & $\mathrm{K} / 2$ & 2.800 .000 \\
\hline \multicolumn{3}{|c|}{ JUMLAH } & & 342.200 .000 \\
\hline
\end{tabular}




\section{Apakah Semua Karyawan PT. ABC Mendapatkan Tunjangan Pph Pasal 21 Setiap Bulan}

Dari hasil penelitian penulis, di PT. ABC tidak semua karyawan mendapatkan tunjangan PPh Pasal 21 setiap bulan. Perhitungan tersebut meliputi objek penghasilan yang dikenakan pajak penghasilan pasal 21 yang dihitung berdasarkan unsur-unsur yang berkaitan meliputi: penghasilan bruto, biaya jabatan, iuran pensiun/Tunjangan Hari Tua/Jaminan Hari Tua, Penghasilan Tidak Kena pajak (PTKP), dan Tarif Pajak Penghasilan Pasal 21. Tunjangan pajak tersebut merupakan penghasilan bagi pegawai yang bersangkutan.

\section{Apakah PT. ABC Terbuka Mengenai Pph Pasal 21 Terhadap Karyawan Yang Sudah Dipotong} Pajak

\section{Dasar Penghitungan Pajak Penghasilan Pasal 21}

Sesuai dengan pasal 21 UU PPh PMK No. 252PMK.03/2008, PPh Pasal 21 dihitung berdasarkan tarif Pasal $17 \mathrm{UU}$ PPh. Sesuai UU PPh, penghasilan pegawai tetap atau pensiunan yang dipotong pajak untuk setiap bulan adalah jumlah penghasilan bruto setelah dikurangi dengan biaya jabatan atau biaya pensiun yang besarnya ditetapkan dengan peraturan Mentri Keuangan, iuran pensiun, dan Penghasilan Tidak Kena Pajak (PTKP).

Secara garis besar Pajak Penghasilan Pasal 21 dihitung berdasarkan rumus berikut ini:

$$
\begin{array}{ll}
\text { PPh Pasal } 21 & =\text { Tarif Pasal } 17 \text { UU PPh x Ph KP } \\
\text { Ph KP } & =\text { Ph Bruto }- \text { Biaya Jabatan }- \text { Iuran Pensiunan }- \text { PTKP }
\end{array}
$$

a. Tarif Pajak

Sesuai dengan Tarif pasal UU No. 36 Tahun 2008 yang berlaku mulai 1 Januari 2009 besarnya tarif pajak adalah :

\begin{tabular}{|l|r|l|}
\hline $\begin{array}{l}\text { Lapisan Penghasilan } \\
\text { Kena Pajak }\end{array}$ & $\begin{array}{l}\text { Tarif } \\
\text { Pajak }\end{array}$ & $\begin{array}{l}\text { Tarif Non } \\
\text { NPWP }\end{array}$ \\
\hline - Sampai dengan Rp50.000.000,- & $5 \%$ & $120 \%$ x 5\%=6\% \\
\hline $\begin{array}{l}\Rightarrow \quad \text { Di atas Rp50.000.000,- s/d } \\
\text { Rp250.000.000,- }\end{array}$ & $15 \%$ & $120 \% \times 15 \%=18 \%$ \\
$\Rightarrow \quad$ Di atas Rp250.000.000,- & $25 \%$ & $120 \% \times 25 \%=30 \%$ \\
s/d Rp500.000.000,- & & \\
$\Rightarrow \quad$ Di atas Rp500.000.000,- & $30 \%$ & $120 \% \times 30 \%=36 \%$ \\
\hline
\end{tabular}




\section{Catatan:}

Berdasarkan Pasal 21 ayat (5a) UU PPh 2008, Wajib Pajak orang pribadi yang tidak mempunyai NPWP akan dikenakan tarif pajak lebih tinggi sebesar 20\% dari tarif normal yang berlaku.

b. Biaya Jabatan

Biaya jabatan hanya boleh dikurangkan dari Penghasilan Bruto Pegawai Tetap karena dianggap sebagai biaya untuk mendapatkan, menagih, dan memelihara penghasilan dari pekerjaan/jabatan pegawai tetap, tanpa memandang apakah yang bersangkutan memiliki jabatan atau tidak.Ketentuan mengenai biaya jabatan adalah sebagai berikut :

\begin{tabular}{|l|l|l|}
\hline Besarnya biaya jabatan & \multicolumn{2}{|l|}{$\begin{array}{l}\text { 5\% x Penghasilan } \\
\text { Bruto }\end{array}$} \\
\hline - Mulai 1 Januari 09 & $\begin{array}{l}\text { Max. Rp 500.000,- } \\
\text { sebulan }\end{array}$ & $\begin{array}{l}\text { Max. Rp 6.000.000,- } \\
\text { Setahun }\end{array}$ \\
\hline
\end{tabular}

Penerapan biaya jabatan maksimal dalam perhitungan PPh Pasal 21 berdasarkan atas jumlah bulan kerja / perolehan yang sebenarnya dari pegawai yang bersangkutan.

c. Iuran Pensiun/THT/JHT

Ketentuan mengenai besarnya iuran pensiun yang dapat dikurangkan dari penghasilan bruto pegawai adalah :

1) Iuran pensiun yang terkait gaji dan dibayarkan kepada dana pensiun yang pendiriannya telah disahkan oleh Menteri Keuangan,

2) Iuran THT kepada badan penyelenggara Taspen dan Jamsostek.

Iuran pensiun atau THT/JHT, sebagian ditanggung oleh Pemberi Kerja, dan sebagian lagi dibayar sendiri oleh karyawan.Yang diperhitungkan sebagai pengurang penghasilan bruto karyawan dalam perhitungan PPh Pasal 21 hanya bagian yang dibayar sendiri oleh karyawan.

Bagi Pemberi Kerja yang mengikutsertakan karyawannya dalam program THT PT Jamsostek (Persero) berlaku ketentuan di bawah ini:

1) Yang dibayar perusahaan $=3,7 \% \rightarrow$ bukan penghasilan karyawan.

2) Yang dibayar karyawan $=2 \% \rightarrow$ pengurang penghasilan bruto karyawan 
Untuk iuran pensiun atau THT yang diikutsertakan pada penyelenggara selain PT Jamsostek, prosentase iuram dapat berbeda-beda.

\section{Penghasilan Tidak Kena Pajak (PTKP)}

Penghasilan Tidak Kena Pajak (PTKP) dalam penghitungan PPh Pasal 21 merupakan batasan penghasilan yang tidak dikenakan pajak bagi orang pribadi yang berstatus sebagai pegawai, baik pegawai tetap, termasuk pensiunan; pegawai tidak tetap, pemagang, dan calon pegawai; termasuk juga pegawai harian lepas, distribusi multilevel marketing/direct selling, petugas dinas luar asuransi, penjaja barang dagangan dan atau penerima penghasilan bukan pegawai lainnya, dengan ketenutan yang berbeda-beda.

Pengaturan besarnya Penghasilan Tidak Kena Pajak adalah :

\begin{tabular}{|c|c|c|c|}
\hline Penerima PTKP & Setahun & \multicolumn{2}{|c|}{ Sebulan } \\
\hline $\begin{array}{l}\text { - Untuk pegawai yang } \\
\text { bersangkutan }\end{array}$ & Rp 24.300.000,- & $\mathrm{Rp}$. & .025 .000 \\
\hline $\begin{array}{l}\text { - } \quad \text { Tambahan untuk } \\
\text { pegawai yang kawin }\end{array}$ & Rp $\quad 2.025 .000,-$ & & $168.750,-$ \\
\hline $\begin{array}{l}\text { - Tambahan untuk } \\
\text { setiap anggota keluarga } \\
\text { sedarah dan semenda dalam } \\
\text { garis keturunan lurus, serta } \\
\text { anak angkat yang menjadi } \\
\text { tanggungan sepenuhnya, } \\
\text { paling banyak 3(tiga) orang. }\end{array}$ & Rp $\quad 2.025 .000,-$ & $\mathrm{Rp}$ & $168.750,-$ \\
\hline
\end{tabular}

\section{Perhitungan Pajak Penghasilan Pasal 21}

Perhitungan Pajak Penghasilan Pasal 21 pada PT. ABC telah sesuai dengan Undang-undang No. 17 tahun 2000. Perhitungan tersebut meliputi objek penghasilan yang dikenakan Pajak Penghasilan Pasal 21 yang dihitung berdasarkan unsur-unsur yang berkaitan meliputi : penghasilan bruto, biaya jabatan, iuran pensiun/Tunjangan Hari Tua/Jaminan Hari Tua, Penghasilan Tidak Kena Pajak (PTKP), dan Tarif Pajak Penghasilan Pasal 21. 
Kebijakan manajemen PT. ABC berkaitan dengan pajak penghasilan pasal 21 menggunakan metode gross-up, dimana karyawan/i diberikan tunjangan Pajak Penghasilan Pasal 21. Tunjangan pajak tersebut merupakan penghasilan bagi pegawai yang bersangkutan, sehingga dalam menghitung Pajak Penghasilan pasal 21 atas gaji pegawai yang bersangkutan, tunjangan pajak tersebut ditambahkan pada penghasilan yang diterimanya. Penulisan akan mencoba untuk menjelaskan secara komperatif cara perhitungan Pajak Penghasilan Pasal 21.

Di dalam perhitungan Pajak Penghasilan Pasal 21, PT. ABC memberikan tunjungantunjangan kepada setiap pegawai tetapnya setiap bulan yang besarnya sesuai dengan peringkat jabatan masing-masing pegawai.

Dengan menggunakan metode ini karyawan akan merasakan puas dan termotivasi, karena PPh 21 yang muncul ditanggung perusahan, karyawan merasa diperhatikan. Perusahan percaya motivasai kepuasan karyawan akan meninggkatkan produktifitas/ kinerja.

\section{Laporan Keuangan}

Laporan keuangan merupakan alat untuk dapat mengetahui apakah kegiatan operasional suatu perusahaan dalam suatu periode dapat menghasilkan keuntungan maupun mengalami kerugian. Berikut ini penulis sajikan laporan keuangan PT. Estika Jasatama. 
Tabel 4.4

PT. ABC

Laporan Neraca

Per 31 Desember 2014

\begin{tabular}{|c|c|c|c|}
\hline \multirow{2}{*}{\multicolumn{2}{|c|}{ KETERANGAN }} & \multicolumn{2}{|c|}{ PPh Pasal 21} \\
\hline & & \multirow{2}{*}{$\begin{array}{c}\text { DITANGGUNG } \\
(0)\end{array}$} & \multirow{2}{*}{$\begin{array}{c}\text { DIGROSS-UP } \\
(0)\end{array}$} \\
\hline AKTIVA & & & \\
\hline $\begin{array}{l}A K T I V A \\
L A N C A R\end{array}$ & & & \\
\hline 1. & Kas & 649.907 .676 & 649.907 .676 \\
\hline 2. & Bank & 2.943 .150 .558 & 2.943 .150 .558 \\
\hline 3. & Piutang Komisi & 2.011.208.599 & 2.011.208.599 \\
\hline 4. & Piutang Pegawai & 716.011 .654 & 716.011 .654 \\
\hline 6. & Biaya Dibayar Dimuka & 1.025.160.992 & 1.025 .160 .992 \\
\hline 7. & Pendapatan Yang Akan Diterima & 36.529 .198 & 36.529 .198 \\
\hline 8. & Pajak Dibayar Dimuka & 409.319 .114 & 409.319 .114 \\
\hline 9. & Piutang Lain-lain & 45.072 .238 & 45.072 .238 \\
\hline & Jumlah Aktiva Lancar & 7.836.360.029 & 7.836.360.029 \\
\hline INVESTASI & & & \\
\hline 1. & Deposito Berjangka & 4.230 .000 .000 & 4.230.000.000 \\
\hline 2. & Investasi Obligasi & 4.500 .000 .000 & 4.500.000.000 \\
\hline AKTIVA TETAP & Jumlah Investasi & 8.730 .000 .000 & 8.730.000.000 \\
\hline
\end{tabular}




\begin{tabular}{|c|c|c|c|}
\hline 1. & Gedung Kantor & 1.889.286.678 & 1.889.286.678 \\
\hline 2. & Rumah Instansi & 320.680 .000 & 320.680 .000 \\
\hline 3. & Kendaraan & 2.071 .021 .716 & 2.071 .021 .716 \\
\hline 4. & Inventaris Kantor & 1.039.286.430 & 1.039.286.430 \\
\hline 5. & Inventaris Rumah Instansi & - & - \\
\hline 5. & Peralatan Komputer & 1.193 .662 .756 & 1.193 .662 .756 \\
\hline & Jumlah Nilai Perolehan & 6.513 .937 .580 & 6.513 .937 .580 \\
\hline & Akumulasi Penyusutan & 4.648.868.037 & 4.648.868.037 \\
\hline & Nilai Buku Aktiva Tetap & 1.865 .069 .543 & 1.865 .069 .543 \\
\hline $\begin{array}{l}A K T I V A \\
L A I N N Y A\end{array}$ & & 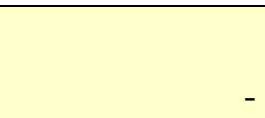 & \\
\hline \multicolumn{2}{|c|}{ JUMLAH AKTIVA } & 18.431.429.572 & 18.431.429.572 \\
\hline \multicolumn{4}{|c|}{ KEWAJIBAN DAN MODAL } \\
\hline \multicolumn{4}{|c|}{ KEWAJIBAN LANCAR } \\
\hline 1. & Hutang Premi & 2.241 .631 .672 & 2.241 .631 .672 \\
\hline 2. & Hutang Komisi & 1.213.251.921 & 1.213 .251 .921 \\
\hline 3. & Hutang Pajak & 1.577 .657 .636 & 1.566 .841 .902 \\
\hline 4. & Biaya Yang masih harus Dibayar & 698.260 .651 & 698.260 .651 \\
\hline 5. & Pendapatan Diterima Dimuka & 915.312 .271 & 915.312 .271 \\
\hline
\end{tabular}




\begin{tabular}{|c|c|c|c|}
\hline 6. & Hutang Lancar Lainnya & 408.602 .514 & 408.602 .514 \\
\hline & Jumlah Kewajiban lancar & 7.054.716.665 & 7.043.900.931 \\
\hline \multicolumn{4}{|l|}{ MODAL } \\
\hline 1. & Modal Saham & 3.000 .000 .000 & 3.000 .000 .000 \\
\hline 2. & Cadangan Umum & 2.517.475.978 & 2.517.475.978 \\
\hline 3. & Cadangan Investasi & 88.300 .350 & 88.300 .350 \\
\hline 4. & $\begin{array}{l}\text { Kenaikan (Penurunan) Surat } \\
\text { Berharga }\end{array}$ & 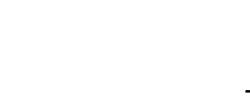 & 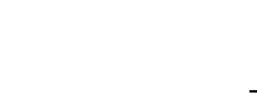 \\
\hline 4. & Laba (Rugi) Ditahan & 5.169 .644 .191 & 5.169 .644 .191 \\
\hline 5. & Laba (Rugi) Tahun Berjalan & 601.292 .388 & 612.108 .122 \\
\hline & JUMLAH MODAL & 11.376.712.907 & 11.387.528.641 \\
\hline \multicolumn{2}{|c|}{ JUMLAH KEWAJIBAN DAN MODAL } & 18.431.429.572 & 18.431.429.572 \\
\hline
\end{tabular}


Tabel 4.5

PT. ABC

Laporan Laba Rugi

1 Januari s/d 31 Desember 2014

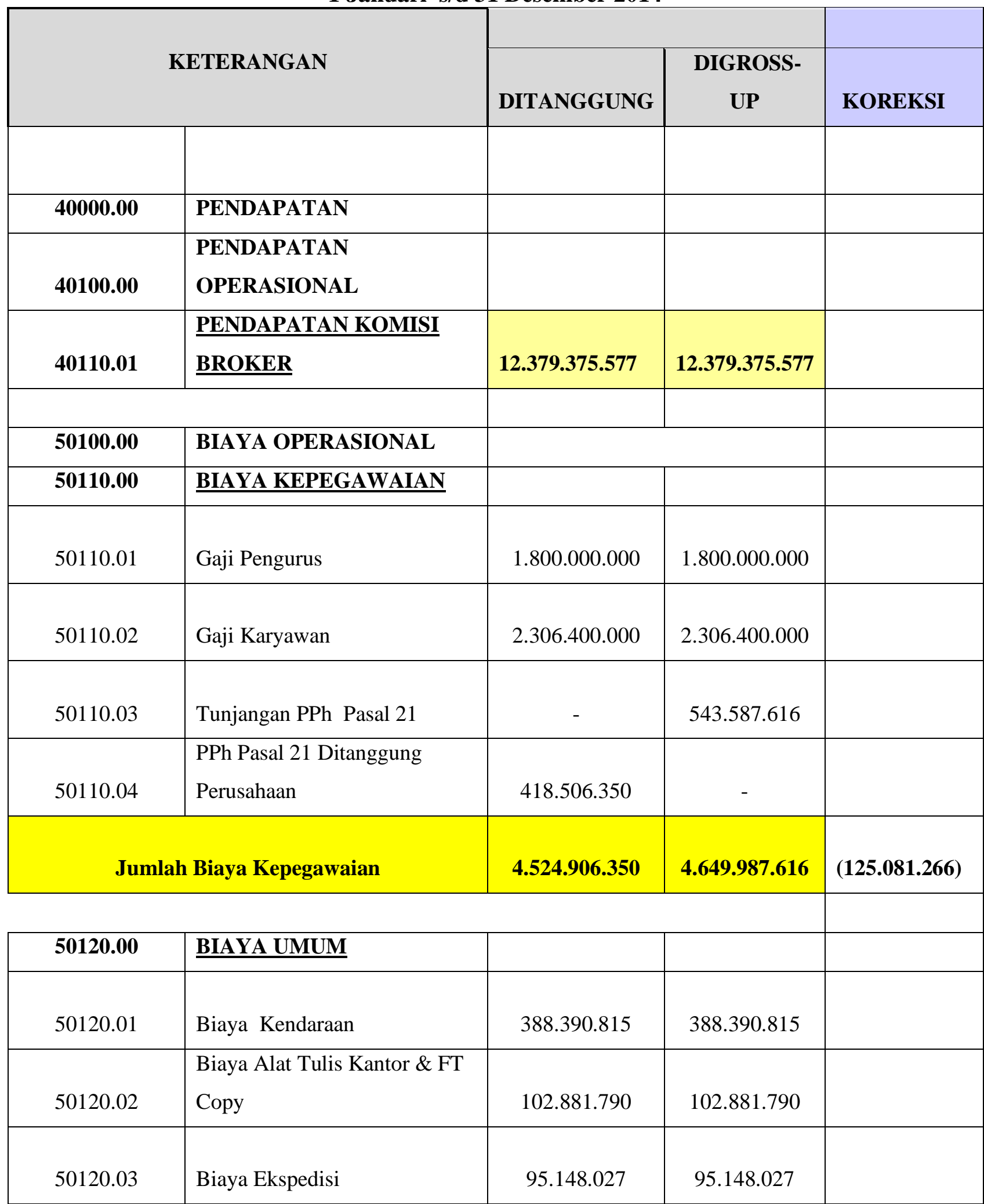




\begin{tabular}{|c|c|c|c|c|}
\hline 50120.04 & Biaya Telpon & 279.119.003 & 279.119.003 & \\
\hline 50120.05 & Biaya Listrik & 89.949 .646 & 89.949 .646 & \\
\hline 50120.06 & Biaya Cetakan & 55.674 .000 & 55.674 .000 & \\
\hline 50120.07 & Biaya Perjalanan Dinas & 90.753 .238 & 90.753 .238 & \\
\hline 50120.08 & Biaya Asuransi & 94.457 .475 & 94.457 .475 & \\
\hline 50120.09 & Biaya Sewa & 780.451 .481 & 780.451 .481 & \\
\hline 50120.10 & Biaya Umum Lainnya & 559.244 .739 & 559.244 .739 & \\
\hline \multicolumn{2}{|c|}{ Jumlah Biaya Umum } & 2.536.070.214 & 2.536.070.214 & . \\
\hline 50130.00 & BIAYA PEMASARAN & & & \\
\hline 50130.01 & Biaya Promosi dan Sponsor & 103.035 .000 & 103.035 .000 & \\
\hline 50130.02 & Biaya Entertaiment & 646.686 .653 & 646.686 .653 & \\
\hline 50130.03 & Biaya Hubungan Masyarakat & 229.388.833 & 229.388 .833 & \\
\hline 50130.04 & Biaya Survei & 297.483 .631 & 297.483 .631 & \\
\hline 50130.05 & Biaya Pemasaran Lainnya & 716.291 .678 & 716.291 .678 & \\
\hline \multicolumn{2}{|c|}{ Jumlah Biaya Pemasaran } & 1.992.885.795 & 1.992.885.795 & \\
\hline 50140.00 & $\begin{array}{l}\text { BIAYA ADMINISTRASI } \\
\text { KEUANGAN }\end{array}$ & & & \\
\hline 50140.01 & Biaya Administrasi Bank & 25.752 .412 & 25.752 .412 & \\
\hline
\end{tabular}




\begin{tabular}{|c|c|c|c|c|}
\hline 50140.02 & Biaya Audit & 50.000 .000 & 50.000 .000 & \\
\hline 50140.03 & Biaya Konsultan / Notaris & 11.150 .000 & 11.150 .000 & \\
\hline 50140.04 & $\begin{array}{l}\text { Biaya Administrasi Keuangan } \\
\text { Lainnya }\end{array}$ & 80.740 .519 & 80.740 .519 & \\
\hline \multicolumn{2}{|c|}{ Jumlah Biaya Administrasi Keuangan } & 167.642 .931 & 167.642 .931 & \\
\hline 50150.00 & $\begin{array}{l}\text { BIAYA PENYUSUTAN } \\
\text { AKTIVA TETAP }\end{array}$ & & & \\
\hline 50150.01 & Penyusutan Gedung Kantor & 3.984 .732 & 3.984 .732 & \\
\hline 50150.02 & Penyusutan Rumah Instansi & 15.791 .576 & 15.791 .576 & \\
\hline 50150.03 & Penyusutan Kendaraan & 465.004 .340 & 465.004 .340 & \\
\hline 50150.04 & Penyusutan Inventaris Kantor & 58.673 .804 & 58.673 .804 & \\
\hline 50150.06 & $\begin{array}{l}\text { Penyusutan Peralatan } \\
\text { Komputer }\end{array}$ & 131.495.924 & 131.495.924 & \\
\hline \multicolumn{2}{|c|}{ Jumlah Penyusutan Aktiva Tetap } & 674.950.376 & 674.950.376 & \\
\hline \multicolumn{2}{|c|}{ JUMLAH BIAYA OPERASIONAL } & 9.896.455.666 & 10.021.536.932 & (125.081.266) \\
\hline \multicolumn{2}{|c|}{ LABA (RUGI) OPERASIONAL } & 2.482.919.911 & 2.357.838.645 & 125.081.266 \\
\hline 40500.00 & $\begin{array}{l}\text { PENDAPATAN NON } \\
\text { OPERASIONAL }\end{array}$ & & & \\
\hline 40510.00 & PENDAPATAN INVESTASI & & & \\
\hline 40510.01 & Pendapatan Bunga Deposito & 305.588 .640 & 305.588 .640 & \\
\hline
\end{tabular}




\begin{tabular}{|c|c|c|c|c|}
\hline 40510.02 & Pendapatan Bunga Obligasi & 477.851 .659 & 477.851 .659 & \\
\hline \multicolumn{2}{|c|}{ Jumlah Pendapatan Investasi } & 783.440 .299 & 783.440 .299 & \\
\hline 40530.00 & $\begin{array}{l}\text { PENDAPATAN NON } \\
\text { OPERASIONAL LAIN }\end{array}$ & & & \\
\hline 40530.01 & Pendapatan Jasa Giro & 49.102 .543 & 49.102 .543 & \\
\hline 40530.02 & $\begin{array}{l}\text { Pendapatan Bunga Pinjaman } \\
\text { Pegawai }\end{array}$ & 22.098 .684 & 22.098 .684 & \\
\hline 40530.03 & Laba (Rugi) Selisih Kurs & 250.193.202 & 250.193.202 & \\
\hline 40530.04 & $\begin{array}{l}\text { Laba (Rugi) Penjualan Aktiva } \\
\text { Tetap }\end{array}$ & 231.579 .139 & 231.579.139 & \\
\hline 40530.05 & $\begin{array}{l}\text { Pendapatan Non Operasional } \\
\text { Lain }\end{array}$ & 173.364 .656 & 173.364 .656 & \\
\hline Jumlah Pen & d. Non Operasional Lain & 726.338 .224 & 726.338 .224 & \\
\hline $\begin{array}{l}\text { LABA (RUGI) SI } \\
\text { PENGHASILAN }\end{array}$ & SBELUM PAJAK & 973.141 .388 & 848.060 .122 & 125.081.266 \\
\hline $\begin{array}{l}\text { PAJAK } \\
\text { PENGHASILAN }\end{array}$ & & 371.849 .000 & 235.952 .000 & 135.897 .000 \\
\hline LABA SETELAF & PAJAK PENGHASILAN & 601.292 .388 & 612.108 .122 & $(10.815 .734)$ \\
\hline
\end{tabular}

\section{Pengaruh Metode Penghitungan Pajak Penghasilan Pasal 21 Dengan Laba Perusahaan}

Berdasarkan laporan laba rugi perusahaan tersebut pada tabel diatas dapat dilihat pengaruh dari ketiga metode perhitungan pajak penghasilan pasal 21 berikut :

a. Metode Ditanggung Oleh Perusahaan besarnya pajak penghasilan pasal 21 sama seperti metode ditanggung karyawan sebesar Rp. 418.506.350,-- , biaya pegawai sebesar 
Rp.4.524.906.350,--, laba sebelum pajak Rp.973.141.388,--pajak penghasilan Rp.371.849.000,-- dana laba bersih setelah pajak penghasilan sebesar Rp.601.292.388,--

b. Metode Digross-up/Diberikan Tunjangan Pajak besarnya pajak penghasilan pasal 21 sebesar Rp. 543.587.616,-- , biaya pegawai sebesar Rp.4.649.987.616,-, laba sebelum pajak Rp.848.060.122,--pajak penghasilan Rp.235.952..000,-- dana laba bersih setelah pajak penghasilan sebesar Rp.612.108.122,--

c. Berdasarkan kedua metode tersebut nampak bahwa metode ditangung/gross up oleh karyawan memberikanbesarnya laba bersih setelah pajak yang paling tinggi sebesar Rp.612.108.122,- namun manajemen mempunyai kebijakan tersendiri dengan tujuan memotivasi karyawannya dengan memberikan tunjangan pajak dengan harapan dapat meningkatkan produktifitas kerja sehingga memilih metode gross-up/diberikan tunjangan pajak dengan jumlah laba bersih setelah pajak penghasilan sebesar Rp.612.108.122,- atau masih lebih tinggi dibanding metode ditanggung oleh perusahaan dengan jumlah laba setelah pajak penghasilan sebesar Rp.601.292.388,---

\section{PENUTUP}

\section{Kesimpulan}

Berdasarkan analisis yang telah dilakukan sebagimana telah dibahas pada bab sebelumnya maka dapat ditarik kesimpulan sebagai berikut:

1. Prosedur pelaksanaan perhitungan $\mathrm{PPh}$ pasal 21 atas gaji pegawai pada PT. ABC menggunakan 3 metode :
a. Metode ditanggung karyawan
b. Metode ditanggung perusahaan
c. Metode groos up

2. Penyebab metode perhitungan $\mathrm{PPh} 21$ pada tingkat laba perusahan masih fluktuasi adalah karena masih ada nya pegawai tidak tetap yang tidak mendapatkan tunjangan pajak. Tunjangan pajak tersebut merupakan penghasilan bagi pegawai yang sudah tetap. Tunjangan-tunjangan yang diberikan setiap pegawai tetap setiap bulan yang besarnya sesuai peringkat jabatan tunjangan tersebut akan mempengaruhi biaya operasional perusahan dan biaya operasioanal tersebut mempengaruhi tingkat laba perusahan sehingga setiap tahunnya terjadinya fluktuasai. 
3. Dari hasil penelitian tidak semua karyawan mendapatkan tunjangan setiapan bulan, karena adanya karyawan magang atau karyawan tidak tetap maka tidak semua karyawan mendapatkan tunjangan.

4. PT. ABC belum terbuka mengenai perhitungan PPh Pasal 21 terhadap karyawan yang bersangkutan, karena gaji karyawan berbeda-beda alasanya PT. ABC tidak terbuka mengenai pajak penghasilan karena ditakutkan adanya kecemburuan sosial antara karyawan.

\section{Saran}

1. Dari hasil analisis data dan kesimpulan yang diperoleh, disarankan perusahaaan menggunakan gross up dalam perhitungan PPh Pasal 21 atas karyawan. Metode gross up memberikan keuntungan kepada kedua belah pihak yaitu karyawan . Dengan metode ini PPh Pasal 21 yang disetor memang paling besar diantara semua metode, namun ada nilai lebih yang didapat karyawan yaitu penghasilan bruto betambah dan take home pay tidak berkurang.

2. Perusahaan dalam menghitung Pajak Penghasilan Pasal 21 karyawan sebaiknya berdasarkan aturan terbaru yaitu peraturan Direktur Jendral Pajak Nomor. PER-31/PJ/2012 yang berlaku mulai tanggal 1 Januari 2013

\section{DAFTAR PUSTAKA}

\section{Buku :}

Mardiasmo.” Perpajakan”. Edisi Revisi, Andi Offset, Yogyakarta, 2013

Undang-Undang Nomor 28 Tahun 2007," Tentang Ketentuan Umum dan Tata Cara Perpajakan."

Waluyo, “Perpajakan Indonesia”, Edisi Revisi, Salemba Empat, Jakarta,2011

\section{Website :}

https://pajakindonesia.wordpress.com/2014/12/02/ptkp-2014/ 